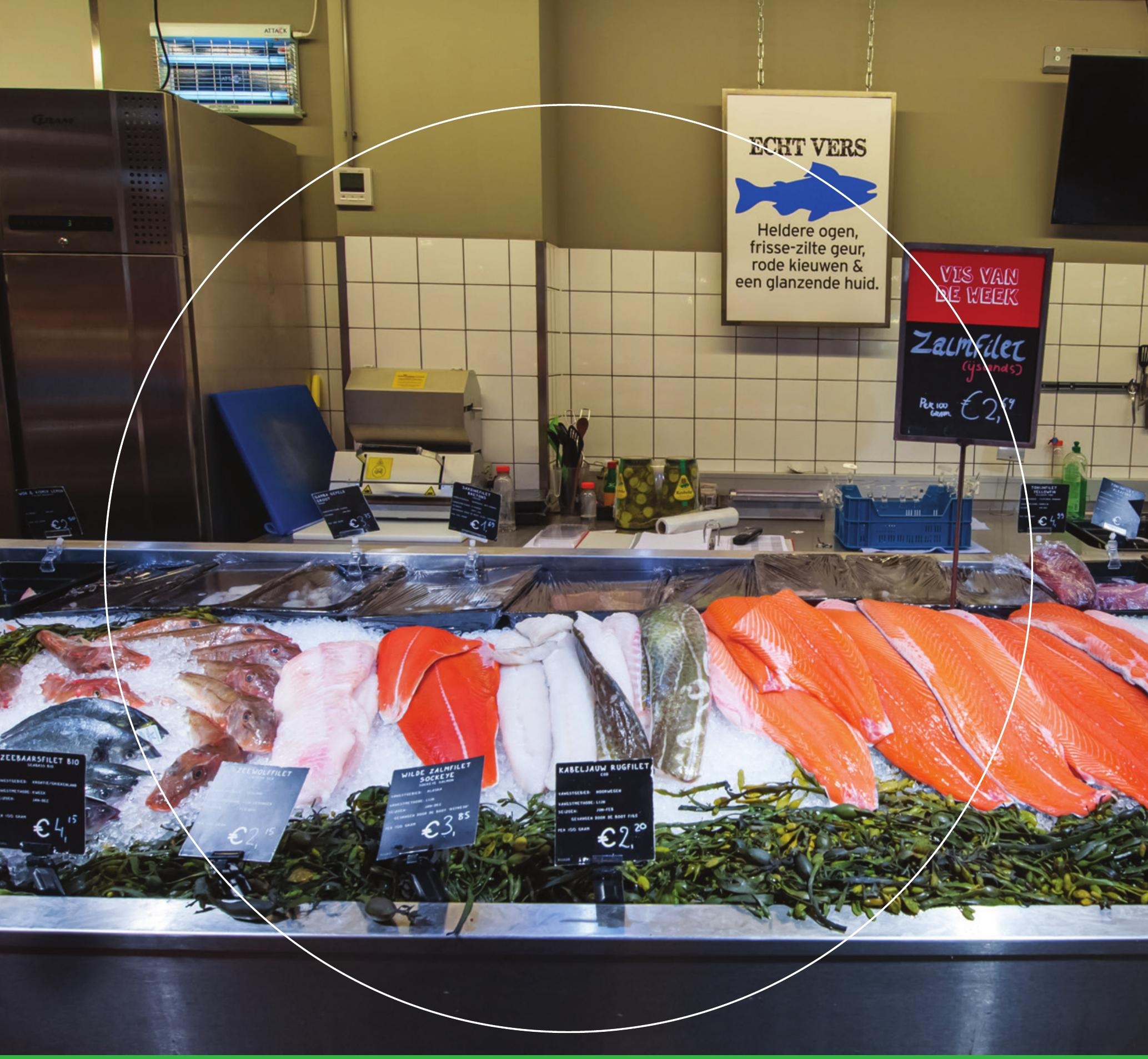

\title{
Communicatie over duurzame vis in de visdetailhandel
}





\section{Wetenschapswinkel}

Communicatie over duurzame vis in de visdetailhandel 


\section{Colofon}

Titel

Trefwoorden

Keywords

Opdrachtgever

Projectuitvoering

Projectcoördinatie

Financiële ondersteuning

Begeleidingscommissie
Communicatie over duurzame vis in de visdetailhandel

Duurzame vis, visdetailhandel, certificering, communicatie

Good Fish Foundation

Bas Janssens, Birgit de Vos en Sien Boschma

Bas Janssens

Wageningen University \& Research

Christine Absil (Good Fish Foundation)

Peter Hamaker (Visspecialist)

Ronald Hoevenaars (Vereniging Nederlandse Visspecialisten)

Maarten Mens (zelfstandige, voorheen Productschap Vis)

Loethe Olthuis (freelance onderzoeksjournalist)

Maud Veraar (Good Fish Foundation)

Nico Waasdorp (detaillist Fish\&Seafood Waasdorp IJmuiden)

Lèneke Pfeiffer (Wetenschapswinkel Wageningen University \& Research)
Fotoverantwoording

Vormgeving

Druk

Bronvermelding

ISBN

DOI
De foto's, kaartjes en figuren zijn vervaardigd door de auteurs of de meewerkende studenten, tenzij anders aangegeven Wageningen University \& Research, Communication Services RICOH, 's-Hertogenbosch Verspreiding van het rapport en overname van gedeelten eruit worden aangemoedigd, mits voorzien van deugdelijke bronvermelding 978-94-6343-228-3 https://doi.org/10.18174/428686

Wageningen, Wetenschapswinkel rapport 339 


\section{Communicatie over duurzame vis in de visdetailhandel}

Rapportnummer 339

S.R.M. Janssens en B.I. de Vos

Wageningen, april 2018

Good Fish Foundation

GFF is een milieuorganisatie die beoogt de visketen verder te verduurzamen. Ze adviseert ketenpartijen bij het verduurzamen van hun visinkoopbeleid, is ontwerper en beheerder van de nieuwe VISwijzer. http://goodfish.guide/ http://www.goedevis.nl/

Wageningen Economic Research Postbus 29703

2585 DB Den Haag
Wageningen University \& Research Wetenschapswinkel

Postbus 9101

6700 HB Wageningen

(0317) 483908

wetenschapswinkel@wur.nl
Wageningen Economic Research Sociaal doet economisch, toonaangevend en onafhankelijk, toegepast onderzoek. De unieke data, modellen en kennis van Wageningen Economic Research bieden opdrachtgevers inzichten en integrale adviezen bij beleid en besluitvorming.

Maatschappelijke organisaties zoals verenigingen en belangengroepen, die niet over voldoende financiële middelen beschikken, kunnen met onderzoeksvragen terecht bij de Wageningen Wetenschapswinkel. Deze biedt ondersteuning bij de realisatie van onderzoeksprojecten. Aanvragen moeten aansluiten bij de werkgebieden van Wageningen University \& Research: duurzame landbouw, voeding en gezondheid, een leefbare groene ruimte en maatschappelijke veranderingsprocessen. 


\section{Inhoud}

$\begin{array}{lll}\text { Voorwoord } & 7\end{array}$

$\begin{array}{lr}\text { Samenvatting } & 9\end{array}$

$\begin{array}{lr}\text { Summary } & 11\end{array}$

$1 \quad$ Inleiding $\quad 13$

1.1 Aanleiding: communicatie over duurzaamheid is beperkt in de visdetailhandel 13

$\begin{array}{llr}1.2 & \text { Probleemstelling } & 14\end{array}$

$\begin{array}{llr}1.3 & \text { Doel } & 14\end{array}$

$\begin{array}{llr}1.4 & \text { Onderzoeksvraag } & 14\end{array}$

$\begin{array}{llr}1.5 & \text { Leeswijzer } & 14\end{array}$

2 Aanpak $r$

$\begin{array}{lll}2.1 & \text { Doelgroep en afbakening } & 15\end{array}$

$\begin{array}{llr}2.2 & \text { Opzet onderzoek } & 15\end{array}$

2.2.1 Verkenning: gestructureerde vragenlijsten $\quad 15$

2.2.2 Diepte-interviews 16

$\begin{array}{ll}2.2 .3 \text { Internet-enquête } & 16\end{array}$

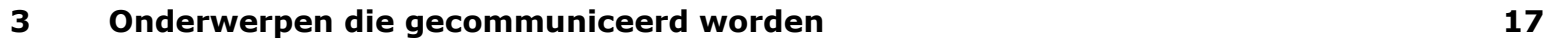

$\begin{array}{llr}3.1 & \text { Respondenten } & 17\end{array}$

$\begin{array}{lll}3.2 & \text { De meeste vis wordt onverpakt verkocht } & 17\end{array}$

3.3 Informatie aan de klant betreft met name prijs, herkomstgebied en of het gaat om wilde of $\begin{array}{ll}\text { kweekvis } & 18\end{array}$

$\begin{array}{ll}3.4 & \text { Onverpakte en verpakte vis } \\ \end{array}$

4 Redenen om wel of niet over duurzaamheid te communiceren 25

$\begin{array}{lll}4.1 & \text { Algemene bevindingen } & 25\end{array}$

4.1.1 De diversiteit van visdetaillisten is groot $\quad 25$

4.1.2 Assortiment en omzet worden gedomineerd door verse en gebakken vis 25

$\begin{array}{ll}\text { 4.1.3 Gebakken vis is meest geconsumeerde product } & 26\end{array}$

4.2 Informatie-uitwisseling tussen visdetaillisten en hun leveranciers is geen bottleneck in $\begin{array}{ll}\text { communicatie naar de consument } & 27\end{array}$

$\begin{array}{ll}\text { 4.2.1 Informatie-uitwisseling tussen leveranciers en visdetaillisten } & 27\end{array}$ 
4.3 Informatie-uitwisseling tussen visdetaillisten en hun klanten

4.4 Redenen om wel/geen informatie te delen vanuit de perceptie van de visdetaillist

4.4.1 Visdetaillisten over hun klanten

4.4.2 Redenen om wel/niet actief te communiceren over vis en duurzaamheid

$5 \quad$ Reflecties

39

6 Bevindingen

43

Literatuur

45

Bijlage 1 Vragenlijst visdetailhandel

47

6 | Communicatie over duurzame vis in de visdetailhandel 


\section{Voorwoord}

Voor milieuorganisatie zijn er veel manieren waarop ze kunnen werken om milieuwinst te boeken. Bewustwordingscampagnes, actievoeren, beleidsbeïnvloeding en rechtszaken zijn bekende middelen. Wij hebben ervoor gekozen om 'via de markt' milieuwinst te boeken: het vergroten van de marktvraag naar duurzame vis. Als de vraag groter wordt, wordt het rendabeler voor vissers om hun visserij te verduurzamen en wordt de markt steeds verder afgesloten voor 'foute vis'.

In 2014 zijn we gestart met de Good Fish Foundation. De supermarkten haakten meteen aan. Via de supermarkten kan er veel druk gezet worden op de visketen. Zo werd bijvoorbeeld 'paling', als ernstige bedreigde vissoort uit het schap gehaald. Maar, een aanzienlijk volume vis gaat via de visdetailhandel (marktaandeel visdetailhandel volgens CBS: ruim 40\%). Toch is deze sector niet eenvoudig mee te krijgen.

De visdetailhandel is een versnipperde markt. Ondernemers zijn individualisten, die op dagelijkse basis bezig zijn hun klanten van kwalitatief goede vis te voorzien. Tijd is geld en een thema als duurzaamheid levert weinig op zo lijkt het credo. Voor visleveranciers en andere ketenpartners geeft de organisatiegraad van visspecialisten ook geen (extra) druk om daadwerkelijk te verduurzamen of te versnellen. Het gevolg is dat supermarkten voorop lopen op het gebied van een verantwoord en traceerbaar visassortiment en de visdetailhandel achterblijft. De kans dat er illegaal gevangen vis, 'slaafvis' of vis waar aan gerommeld is in de viswinkel ligt is vele malen groter dan in de supermarkt. Het risico voor reputatieschade van deze branche ligt op de loer.

Hoe kunnen we als milieuorganisatie dan toch zorgen dat deze sector verduurzaamt? Wij zien wel erg mooie kansen! Visspecialisten kunnen zich onderscheiden ten opzichte van supermarkten door een divers duurzaam aanbod van (regionaal) gevangen en gekweekte vis. De visspecialist kan het verhaal achter de vis overbrengen. Door betrouwbare informatie te geven kan de "visboer", als ambachtsman, zich onderscheiden. De detailhandel kan meer dan nu de 'brug' kunnen zijn tussen de visser en de consument en hen kunnen enthousiasmeren voor de consumptie van (lokale) duurzaam gevangen vis. Het onderzoek 'Communicatie over duurzame vis in de visdetailhandel' van de Wetenschapswinkel geeft goede inzichten in de beeldvorming van ondernemers over het thema duurzaamheid en de vertaling daarvan naar hun klanten. Het rapport bevestigt de enorme uitdagingen die wij ook zien om veranderingen in de visdetailhandel door te voeren. Good Fish Foundation beraamt zich op een effectief plan van aanpak, waarvoor het onderzoek goed gebruikt gaat worden. Het is fantastisch dat de Wetenschapswinkel dit mooie rapport heeft opgesteld en we zijn hen dan ook erg dankbaar!

Maud Veraar

Directeur

Good Fish Foundation 


\section{Samenvatting}

Op verzoek van Good Fish Foundation heeft Wetenschapswinkel Wageningen UR onderzoek laten doen naar de communicatie over duurzame vis in de visdetailhandel.

Uit de verkenning en de diepte-interviews onder visdetaillisten blijkt dat het communiceren over duurzame vis geen gemeengoed is in de visdetailhandel, hoewel het wel verschilt per productgroep. Bij verse vis wordt eerder duurzaamheidsinformatie gecommuniceerd dan bij producten zoals gebakken vis en eigen bereidingen zoals salades.

Uit het onderzoek komen een aantal interessante zaken naar voren:

- De diversiteit onder visdetaillisten is groot: de bedrijfstypen (winkel, verkoopwagen, marktkraam), de verkooplocatie en de klantenkring zijn van invloed op het verkochte assortiment en dus op de communicatie.

- De informatie die alle visdetaillisten communiceren zijn naam en prijs van de vis, op het label bij de vis in de toonbank. Het label is echter te klein voor het opnemen van extra informatie. Duurzaamheidsinformatie over herkomst, vangsttechniek en vis van het seizoen wordt daardoor vaak op andere manieren gecommuniceerd: o.a. via poster, beeldscherm of mondeling.

- Visdetaillisten hebben meerdere leveranciers: voor verse vis, gerookte vis en verpakte of ingevroren vis. Visdetaillisten geven aan dat zij de benodigde duurzaamheidsinformatie van hun leveranciers krijgen of zouden kunnen krijgen. Aandachtspunten zijn of de doorstroming van deze informatie meer geüniformeerd kan worden en of deze ook daadwerkelijk door de visdetaillist wordt gebruikt. Slechts een beperkt aantal visdetaillisten heeft zelf een erkend duurzaamheidscertificaat (MSC, ASC). Ondervraagde visdetaillisten geven aan dat de kosten en moeite voor certificering hoog zijn in verhouding tot de omzet die men er mee realiseert. Ook heeft het certificaat vaak maar betrekking op een deel van het totale assortiment. Een groot deel van de visdetaillisten meent dat hun klanten niet geïnteresseerd zijn in duurzame vis. Of dit daadwerkelijk zo is, zou onderzocht moeten worden. Het belangrijkste motief om een visdetailzaak te bezoeken zijn kwaliteit, vers en het persoonlijke contact. Visdetaillisten geven aan dat hun klanten de VISwijzer maar sporadisch gebruiken. Enkele visdetaillisten vertellen hun klanten het verhaal bij de duurzame vis. Dit vergroot het bewustzijn waarbij deze klanten geneigd om vaker duurzame vis te kopen.

Doel van het onderzoek was ook een nulmeting onder de visdetaillisten te voeren. Omdat het niet gelukt is de benodigde financiële middelen te organiseren kon geen uitgebreide enquête worden afgenomen. 


\section{Summary}

At the request of the Good Fish Foundation, Science Shop Wageningen UR has commissioned research on the communication about sustainable fish in the fish mongers sector.

The survey and the in-depth interviews among fish mongers show that communicating about sustainable fish is not common in the fish mongers sector, although it differs per product group. In the case of fresh fish, sustainability information is communicated more frequently than in products such as fried fish and in-house preparations such as salads. A number of interesting issues emerge from the research:

- The diversity among fish mongers is large: the business types (store, sale trailer, market stall), sales locations and the composition of the clientele influence the assortment sold and thus the communication.

- The information that all fish mongers communicate is the name and price of the fish, on the label with the fish in the counter. However, labels are too small to include additional information. As a result, sustainability information about origin, fishing technique and fish of the season is often communicated in other ways: e.g. via poster, screen or orally.

- Fish mongers have several suppliers: for fresh fish, smoked fish and packaged or frozen fish. Fish mongers indicate that they receive or could obtain the required sustainability information from their suppliers. A point of attention is whether the flow of this information can be more uniformed. Only a very small number of fish mongers have a recognized sustainability certificate (MSC, ASC). Interviewed fish mongers indicate that the costs and effort for certification are high in relation to the turnover that they realize. Furthermore, the certificate often only relates to a part of the total range. Many of the fish mongers believe that their customers are not interested in sustainable fish. Whether this is indeed so, should be investigated. The most important motive for consumers to visit a fish retail store is quality, fresh fish and personal contact. Fish mongers indicate that their customers use the VISwijzer sporadically. Some fish mongers tell their customers the story about the sustainable fish. This increases the awareness that these customers are inclined to buy sustainable fish more often.

The aim of the research was to conduct a baseline measurement among the fish mongers. Because it was not possible to organize the necessary financial resources, no extensive survey could be conducted. 


\subsection{Aanleiding: communicatie over duurzaamheid is beperkt in de visdetailhandel}

De visdetailhandel, bestaande uit gespecialiseerde viswinkels en ambulante handel (viskraam), is het punt in de visketen waar het totale visassortiment bij elkaar komt. Vanwege het directe contact met de consument, en omdat echte visliefhebbers bij voorkeur naar de visdetailhandel gaan, zou deze branche dé schakel kunnen zijn om te communiceren over duurzaamheid. Echter, uit een steekproef blijkt dat een groot gedeelte van de vis in de vitrine rood scoort op de VISwijzer en dat er niet of nauwelijks wordt gecommuniceerd over vangstgebieden en vangsttechnieken (bron: GFF, april 2015), ondanks de wettelijke verplichting (2014) om deze gegevens aan de consument te verstrekken. In dit onderzoek kijken we daarom naar het verhaal achter het niet of nauwelijks communiceren over duurzaamheid, gezien vanuit de Nederlandse visdetailhandel (viswinkel, viskraam). Centraal staat welke informatie de visdetaillist communiceert over duurzame vis richting consument, of en hoe deze informatie wordt verstrekt en welke belemmeringen de visdetaillist daarbij ervaart.

\section{De sector: er is een groeiend aantal viswinkels in Nederland}

De visdetailhandel telt ongeveer 1.700 bedrijven. Het aantal gespecialiseerde viswinkels in sinds 2007 met 25 procent toegenomen. Waren er in 2007 nog 650 viswinkels in Nederland, in 2014 was dit aantal gestegen tot 815 (website VNV). Volgens detailhandel.nl zijn er 891 viswinkels (februari, 2016). Een kwart van de viswinkels is in Noord-Holland gevestigd (o.a. veel viswinkels in Amsterdam). Flevoland heeft met 15 viswinkels de minste visboeren (CBS, 2015). De ambulante handel is ongeveer even groot (exacte cijfers zijn onbekend). In 2014 hadden de viswinkels een marktaandeel van bijna $22 \%$. De supermarkten hadden het grootste marktaandeel (rond 60\%). De straathandel had een aandeel van $12 \%$ (bron: detailhandel.info). Tenslotte kunnen we zeggen dat het marktaandeel van de visdetailhandel ten opzichte van supermarkten onder druk staat. Ook lijkt de branche van visdetaillisten een achterstandspositie te hebben op het gebied van een verantwoord en traceerbaar inkoopbeleid ten opzichte van supermarkten (Volkskrant, 26 november 2015).

\section{Consument bezoekt de viswinkels vanwege kwaliteitsaspect}

Consumenten hechten steeds meer waarde aan duurzaam voortgebrachte agrarische voedselproducten, zoals vis die duurzaam is gevangen. Hulpmiddelen zoals keurmerken en de VISwijzer (www.goedevis.nl) kunnen de consument helpen deze informatie te verwerken. Vanwege de focus op kwaliteit, vertrouwen consumenten er op dat visdetaillisten een duurzamer aanbod hebben dan bijvoorbeeld supermarkten. Visdetaillisten onderscheiden zich van supermarkten door de verkoop van verse vis met eigen labels, een breed assortiment, het verhaal van de visserman te vertellen en/of vis van het seizoen te verkopen (Melissant et al, 2014). Het gebruik maken van duurzaamheidskeurmerken, zoals MSC/ASC ${ }^{1}$, is voor visdetaillisten vaak niet aantrekkelijk omdat er aan veel eisen voldaan moet worden om gecertificeerd te raken. Dit blijkt ook uit het feit dat slechts 15 van de 815 winkels is gecertificeerd met het MSC-keurmerk (Elsevier, 2016).

\section{Communicatie is verplicht vanuit wet- en regelgeving (www.nvwa.nl)}

De NVWA controleert voortdurend de veiligheid van vis en visproducten. Dit doet de NVWA samen met andere publieke en particuliere instanties en met verschillende methoden. Ook geldt de traceringsverplichting visserij- en aquacultuurproducten ${ }^{2}$ waarop de NVWA controleert: de verplichte informatie die op het etiket ${ }^{3}$ vermeld moet worden (EU, 2014). Handhaving op gebruik van keurmerken van duurzame gevangen of gekweekte vis valt buiten de taken van de NVWA.

\footnotetext{
${ }^{1}$ MSC staat voor Marine Stewardship Council, ASC voor Aquaculture Stewardship Council. MSC is een onafhankelijke organisatie die een internationaal erkend milieukeurmerk en certificeringsprogramma heeft ontwikkeld voor duurzame wildvangst visserijen. ASC is een onafhankelijke internationale non-profit organisatie die een certificeringsprogramma voor verantwoorde viskweek beheert en verder ontwikkelt. ${ }^{2}$ Visserijproducten en aquacultuurproducten die in de EU (waarschijnlijk) in de handel worden gebracht moeten, om aan de traceringsverplichtingen te voldoen, een etiket of andere informatiedrager bevatten. Hierop moeten gegevens staan over onder andere de handelsbenaming, de productiemethode en het vangstgebied.

3 Etiket: Op vis moet staan in welk gebied het product is gevangen of gekweekt en in geval van wildvangst sinds 2014 de gebruikte categorie vistuig; (zie ook Europese Unie, 2014). Na de 1e verkoop en voordat de partij vis door de koper wordt afgevoerd, dienen de partijen verkochte vis door de bemiddelaar/afslag of de $1 \mathrm{e}$ koper te worden voorzien van een etiket (of andere informatiedrager).
} 


\subsection{Probleemstelling}

Dagbladartikelen (Olthuis, 2015; Rommy van der Poel, 2016)) melden dat de communicatie vanuit de visdetailhandel naar consumenten over de duurzaamheid van de aangeboden vis te wensen over laat. GFF wil inzicht in de omvang hiervan en heeft behoefte aan een onderbouwing van de manier waarop duurzame vis door de visdetailhandel aan consumenten wordt aangeboden en gecommuniceerd. GFF wil inzicht hoe en in hoeverre de informatie over de duurzaamheid van vis richting consumenten wordt verstrekt en wat de onderliggende redenen zijn waarom dit wel of niet wordt gedaan. Dit biedt GFF de mogelijkheid om na eventuele vervolgactiviteiten van GFF, die gericht zijn op verandering in de sector/branche, te meten in hoeverre deze activiteiten succesvol zijn geweest.

\subsection{Doel}

Het doel van dit onderzoek is om de manier waarop de Nederlandse visdetailhandel (viswinkel, viskraam) communiceert over duurzaamheid van vis naar hun klanten inzichtelijk te maken. Centraal staat welke informatie de visdetaillist communiceert over duurzame vis richting consument, of en hoe deze informatie wordt verstrekt en welke belemmeringen de visdetaillist daarbij ervaart. Het betreft met name informatieverstrekking door de visdetaillist aan consumenten over herkomst (gebied, kweek of wild gevangen) en vangmethode ofwel issues die een rol zouden kunnen spelen bij het tegengaan van overbevissing en goed beheer van visbestanden.

\subsection{Onderzoeksvraag}

Het onderzoek beoogt antwoord te geven op de volgende vragen en sub-vragen:

- Weet de visdetailhandel van de wettelijke verplichting om gegevens over vangstgebieden en vangsttechnieken te verstrekken?

- Voldoen ze eraan?

- Waarom wel of niet?

- Welke rol spelen andere schakels in de keten bij deze informatieverstrekking?

- Waar is behoefte aan?

- Op welke wijze communiceert de visdetailhandel over duurzaamheid (b.v. gebruik van labels, vis van het seizoen)?

- Wat verstaat de visdetaillist onder duurzaamheid?

- Welke rol spelen andere schakels in de keten bij deze informatieverstrekking?

- Welke zijn de belemmeringen? (Bij visboer, in voorliggende ketenschakels)

\subsection{Leeswijzer}

In hoofdstuk 2 wordt de opzet en aanpak van het onderzoek beschreven. In het volgende hoofdstuk worden de resultaten van de verkenning gepresenteerd. Hoofdstuk $5 \mathrm{geeft}$ een overzicht van de belangrijkste bevindingen van de interviews. In de volgende hoofdstukken worden respectievelijk discussiepunten en conclusies uiteengezet. 


\section{Aanpak}

\section{$2.1 \quad$ Doelgroep en afbakening}

In dit onderzoek staat de visdetailhandel centraal. In de visdetailhandel zijn verschillende groepen van detaillisten actief, elk met een eigen verkoopformule. Onderscheiden worden viswinkels en ambulante handel.

\section{Er zijn drie type viswinkels}

De volgende verkoopformules voor viswinkels worden onderscheiden (Productschap vis, 2011):

1. De viswinkel met traditioneel assortiment. In deze winkel of kiosk wordt voornamelijk het traditionele assortiment (nieuwe haring, gebakken vis, verse vis) verkocht en is consumptie ter plekke mogelijk;

2. De viswinkel/traiteur. Naast de verkoop van verse vis worden in dit winkeltype naar verhouding veel traiteurs producten (belegde broodjes, vissoepen, salades, schotels e.d.) aangeboden. Bijna altijd kan een aantal producten ook ter plekke worden genuttigd. Ondernemers met dit winkeltype hebben vaak ook cateringactiviteiten;

3. De viswinkel met lunchroom of de eetviswinkel (seafood bar). In deze winkel met ruime zit- en eetgelegenheid wordt de verkoop van vis en visproducten gecombineerd met horeca-activiteiten.

Consumenten kunnen hier lunchen, dineren maar ook een kopje koffiedrinken 'met iets erbij'.

Alle drie de verkoopformules hebben vanuit de consument gezien een andere functie.

\section{Ambulante handel}

De volgende verkoopformules worden voor de ambulante handel onderscheiden:

1. De viskraam op de warenmarkt;

2. De verkoopwagen op de warenmarkt en bij evenementen. In vergelijking met de ondernemer die de kraam heeft, kunnen de producten van een verkoopwagen beter gekoeld worden;

3. Op een solitaire standplaats(en) met een min of meer mobiele verkoopwagen of een kiosk. Kenmerkend voor deze vishandelaren is dat men wekelijks met de verkoopwagen op meerdere standplaatsen staan en de consumenten meer opzoekt.

In het onderzoek staat de communicatie over duurzame vis door visdetailhandel centraal. Daarbij zijn ook de leveranciers en klanten van visdetaillisten zijdelings in ogenschouw genomen. Vissers, supermarkten (retail), restaurants (food service) en consumenten vallen buiten de doelgroep van dit onderzoek.

\subsection{Opzet onderzoek}

Het onderzoek is gefaseerd opgebouwd en bestond uit de volgende onderdelen:

1. Verkenning

2. Diepte-interviews

3. Internet-enquête

\subsubsection{Verkenning: gestructureerde vragenlijsten}

De verkenning is gericht op een eerste (grove) inventarisatie van de problematiek en bedoeld om meer focus te krijgen. Hiervoor zijn gestructureerde face to face interviews afgenomen onder de bezoekende visspecialisten van de nationale Verspiratiedagen te Nijkerk op 7 en 8 maart 2016. Voor deze interviews is een beknopte vragenlijst (bijlage 1 ) met gesloten vragen opgesteld door Wageningen Economic Research in samenwerking met de Good Fish Foundation (GFF). De interviews zijn afgenomen door onderzoekers van Wageningen Economic Research en medewerkers van GFF. De vragenlijsten zijn verwerkt en geanalyseerd door onderzoekers van Wageningen Economic Research. 
De resultaten van de verkenning geven een eerste indruk van de mate en manier waarop visdetaillisten informatie verstrekken over duurzaam gevangen vis op het moment dat zij deze aan hun klanten verkopen ('over de toonbank').

\subsubsection{Diepte-interviews}

Of en welke duurzaamheidsinformatie bij de vis aan klanten wordt verstrekt is onder andere afhankelijk van het feit of visdetaillisten de desbetreffende informatie ontvangen van hun leveranciers: afslag, groothandel, visverwerkende bedrijven of visserman. Ofwel hoe wordt duurzaamheidsinformatie per vissoort in de keten doorgegeven? En zo ja, welke duurzaamheidsinformatie wordt doorgegeven en hoe gebeurt dat? En wat is de rol van de visdetaillisten in dit verband?

Daarnaast is het ook essentieel te begrijpen hoe visdetaillisten aankijken tegen de communicatie van duurzaamheid (relevant, haalbaar etc.) en hoe zij het denken en handelen van hun klanten/consumenten bij de aankoop van duurzame vis beoordelen. Om diepgaander inzicht in te krijgen zijn in fase 2 diepte-interviews gehouden onder visdetaillisten en -handel en relevante stakeholders. Doel van deze uitgebreide interviews is onduidelijkheden uit de verkenning en achtergronden verder uit te diepen aan de hand van een lijst open vragen. Dit onderdeel van het onderzoek is uitgevoerd door en in samenwerking met een MSc-student van de opleiding van HallLarenstijn te Velp die tijdens haar opleiding via stages en vakken al enige ervaring opgedaan in de duurzame visserij. Ze heeft de resultaten van haar onderzoek vastgelegd in een uitgebreide rapportage (Boschma, 2016). De interviews zijn afgenomen op locatie, bij visdetaillisten en -handel. In totaal zijn tien interviews afgenomen. Om efficiency-redenen (reistijd) is de regio beperkt tot Noord-Holland en omgeving Arnhem.

\subsubsection{Internet-enquête}

Het laatste deel van het onderzoek beoogt een zogenaamde nulmeting uit te voeren onder een zo groot mogelijke groep visdetaillisten. Deze nulmeting wordt gedaan via een internet-enquête. Bij aanvang van het onderzoek was de financiering van dit onderdeel nog niet ingevuld en was als optie in de begroting opgenomen. Omdat het uiteindelijk niet is gelukt financiële middelen voor fase 3 te organiseren is dit onderdeel vervallen. Wel is ter voorbereiding van dit onderdeel gekeken naar de opzet van de vragenlijsten voor en internet-enquête. In samenwerking met Wageningen University onderzoeksgroep Research Methodology hebben twee groepjes studenten in het kader van hun onderwijsmodules model-enquêtes uitgewerkt en een proefinterview uitgevoerd. Het bleek niet mogelijk deze studenten in het kader van hun studie de beoogde enquête te laten uitvoeren. 


\section{Onderwerpen die gecommuniceerd worden}

Tijdens de interviews is informatie verzameld over: omvang assortiment, beschikbaarheid informatie duurzaamheid (o.a. herkomst, vangstmethode), manier van communicatie, rol ondernemer m.b.t. duurzaamheid o.a. proactief, personeel (kennis duurzaamheid + scholing), type klanten, rol klanten duurzaamheid, ervaren belemmeringen, etc. Dit hoofdstuk geeft een overzicht van de resultaten.

\subsection{Respondenten}

Tijdens de Verspiratiedagen zijn totaal 25 interviews afgenomen. Van de respondenten heeft bijna tweederde (64\%) aangegeven te werken in een viswinkel, de anderen werken in een viskraam of verkoopwagen (figuur 3.1). 84\% van de respondenten gaf aan eigenaar te zijn. Twee respondenten gaven aan dat ze in traditionele visserijplaatsen vis verkopen (Urk, Katwijk). De ondervraagde beursbezoekers vormen geen representatieve afspiegeling van de doelgroep (viswinkels zijn oververtegenwoordigd) en de indruk is dat een groot deel van hen tot voorlopers gerekend kunnen worden.

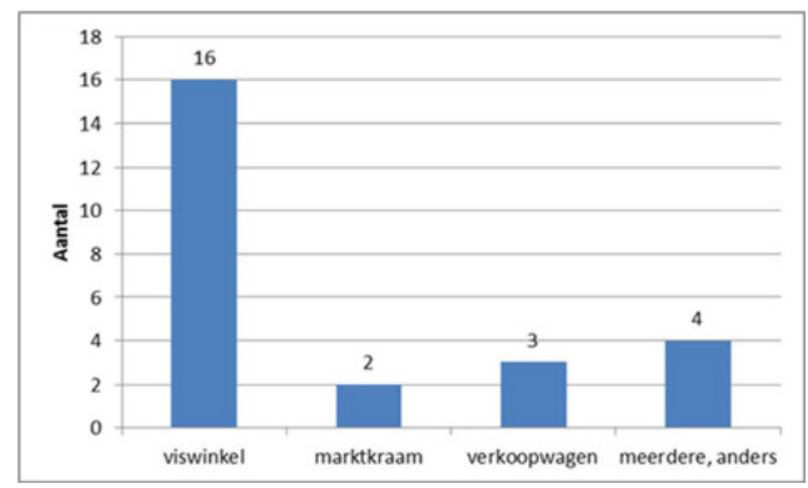

Figuur 3.1 Aantal respondenten per bedrijfstype

\subsection{De meeste vis wordt onverpakt verkocht}

De respondenten is gevraagd of zij hun vis verpakt of onverpakt verkopen. Verpakt hebben we gedefinieerd als: verpakt ingekocht en deze ongeopend (door)verkocht. 84\% van de verkochte vis wordt onverpakt verkocht (onverpakt ingekocht of in de zaak uit de verpakking gehaald). Dit betreft verse vis, gebakken vis, of uit verpakking gehaalde vis om te portioneren. Redenen om vis uit de verpakking te halen zijn dat de inhoud van de verpakking te groot is voor klanten, of verpakt wordt aangeleverd en voor bereiding wordt uitgepakt (o.a. kibbeling). Zestien procent van de verkochte vis wordt verpakt doorverkocht. 


\subsection{Informatie aan de klant betreft met name prijs, herkomstgebied en of het gaat om wilde of kweekvis}

In de viswinkel of -kraam kan informatie via verschillende kanalen aan klanten worden 'verstrekt': via een label bij de vis in de vitrine, via een monitorscherm dat in de zaak staat, of mondeling. Een andere mogelijkheid is dat de informatie wordt niet gecommuniceerd. Beursbezoekers is gevraagd welke informatie zij op welke manier met hun klanten in de winkel communiceren over verse, onverpakte vis.

\section{Prijs}

Alle respondenten (100\%) geven aan dat ze de prijs van de vis op een label of kaartje bij de vis vermelden. Andere manieren waarop prijzen (met name aanbiedingen) aan klanten op de verkoopplek gecommuniceerd worden zijn een monitor of posters. Ook vragen klanten soms om de prijs. Ongeveer de helft van de respondenten vermeld de prijs ook op een andere manier dan het label.

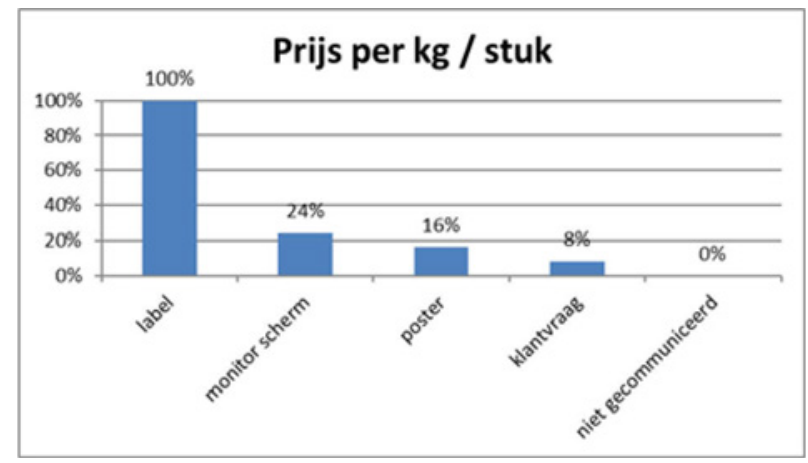

Figuur 3.2 Meest gebruikte kanalen voor het vermeden van de prijs van de vis.

\section{Latijnse naam}

Ruim een kwart van de respondenten geeft aan de Latijnse naam van de vis in de vitrine op een label bij de vis vermelden. Andere communicatiekanalen worden niet gebruikt. Bijna driekwart communiceert de Latijnse naam niet omdat deze de meeste klant niets zegt.

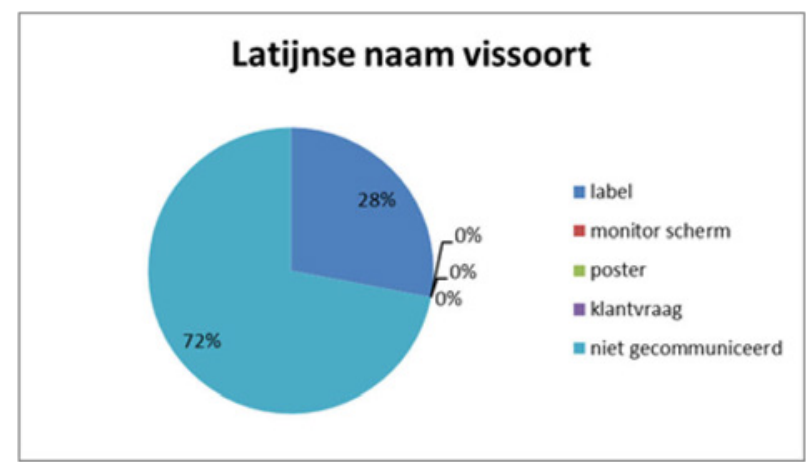

Figuur 3.3 Meest gebruikte communicatiekanalen voor Latijnse naam van de vissoort.

\section{Herkomstgebied}

Het gebied waar de vis is gevangen, het herkomstgebied, wordt door bijna twee derde van de respondenten gecommuniceerd, vooral via het label. Vaak wordt het herkomstgebied in de naamgeving van de vis opgenomen en gecommuniceerd: 'Noorse zalm', 'Schotse zalm', 'Noordzee kabeljauw', 'Hollandse of Noordzee garnalen'. 


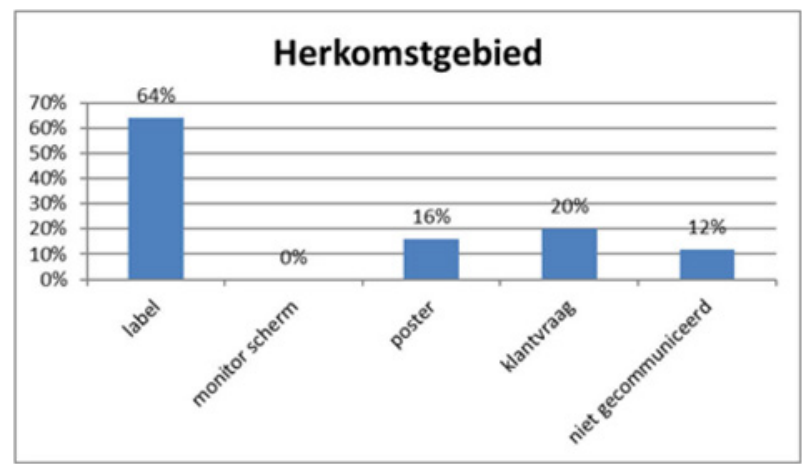

Figuur 3.4 Meest gebruikte communicatiekanalen voor het herkomstgebied van de vis.

\section{Vangstmethode}

In de viswinkel of -kraam wordt zelden vermeld, hoe de vis gevangen is. De vangstmethode wordt zelden actief gecommuniceerd. Dit gebeurt pas als de klant erom vraagt. Een enkeling vermeld de vangstmethode op het label. Voorbeelden van vangstmethoden die in de Viswijzer worden aangegeven zijn: 'ringzegen, kieuwnetten (staand want), zwevende ottertrawls en sleepnetten. Op verpakking labels wordt 'met trawlnetten' vermeld. Bij kweekvis wordt de kweekmethode vermeld zoals 'vijverteelt intensief'.

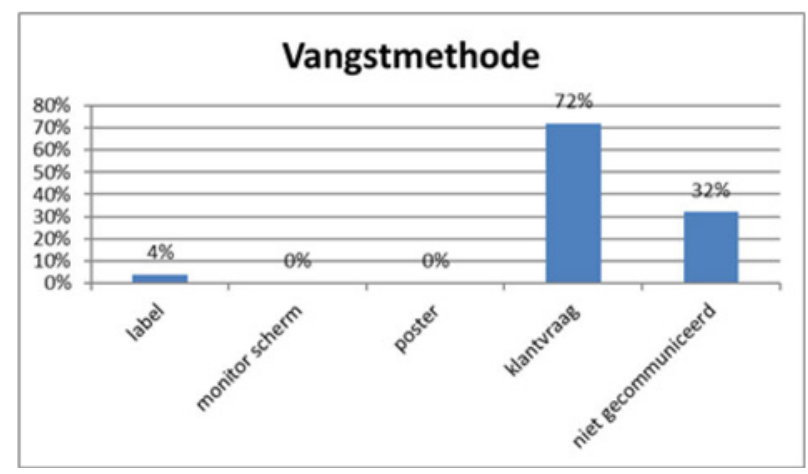

Figuur 3.5 Communicatie over de vangstmethoden van vissoorten.

\section{Vers of bevroren}

Vis die niet bevroren is geweest, is verse vis. Gevraagd is of visdetaillisten vermelden of de vis die ze verkopen bevroren is of is geweest. Ruim een derde van de respondenten geeft op het label aan of de vis bevroren is (geweest). Twee derde van de respondenten communiceert dit niet actief; de helft van hen geeft aan de klant wel te informeren als deze erom vraagt. 


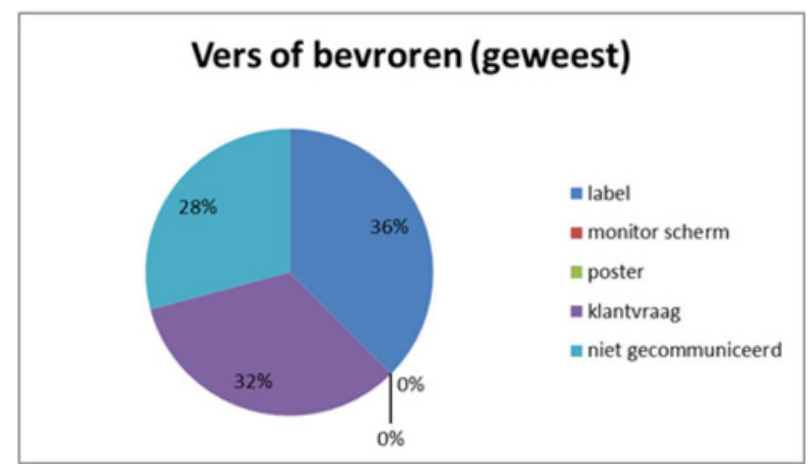

Figuur 3.6 Communicatie verse en bevroren vis.

\section{Houdbaarheidsdatum}

Ruim tien procent van de respondenten communiceert de houdbaarheidsdatum via het label. Bijna negentig procent meldt/communiceert geen houdbaarheidsdatum. Wel geeft bijna de helft van de correspondenten aan dat zij de houdbaarheidsdatum mondeling communiceren als de klant erom vraagt. Bij deze vraag is geen exacte definitie voor houdbaarheidsdatum gegeven: het kan bijvoorbeeld zijn een de klant vraagt 'is de vis vers'? De klant bedoeld in dit geval dat de vis net is ingekocht/aangevoerd (verse aanvoer) en kort in de vitrine ligt (binnen de houdbaarheidstermijn). Met de vraag bedoelt de klant niet of de vis ingevroren is geweest.

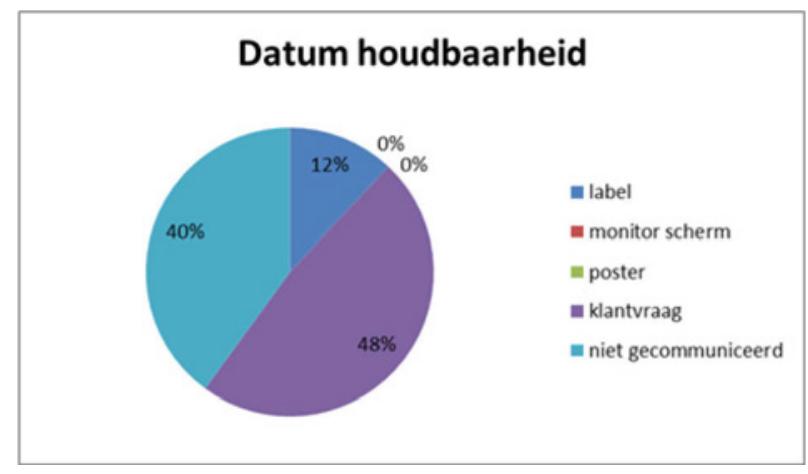

Figuur 3.7

Communicatiekanalen datum houdbaarheid.

\section{Seizoeninformatie}

Elke vissoort heeft een periode in het jaar dat deze goed verkrijgbaar is (viskalender). Veertig procent van de respondenten geeft actief informatie over 'vis van het seizoen' (figuur 3.8). Met vlaggetjesdag wordt het nieuwe haringseizoen ingeluid. Visdetaillisten haken hierop in en communiceren 'nieuwe haring' als seizoeninformatie. Voor andere vissoorten wordt seizoeninformatie minder vanzelfsprekend richting de consument gecommuniceerd.

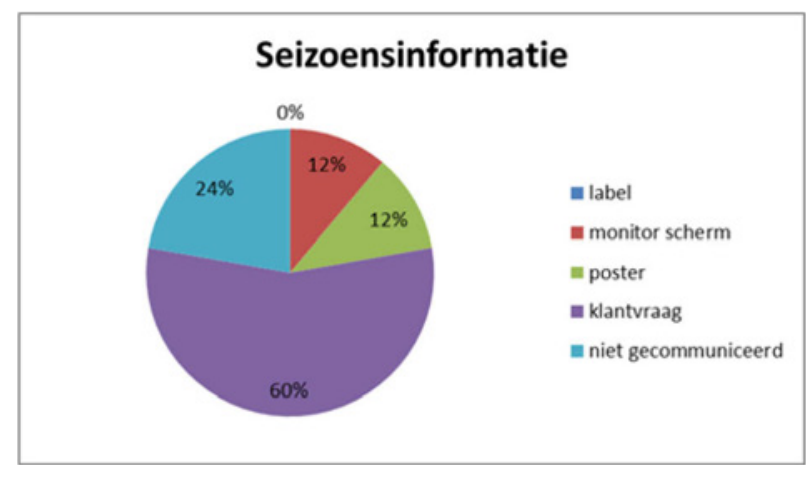

Figuur 3.8 Verstrekken seizoen informatie.

20 | Communicatie over duurzame vis in de visdetailhandel 


\section{Kweek of wild gevangen}

Zestig procent van de respondenten zegt op het label te vermelden of het betreffende product kweekvis betreft. Nog eens ruim een kwart van de respondenten vertelt dit als de klant ernaar vraagt. Ruim tien procent communiceert niet of het om kweek- of wild gevangen vis gaat.

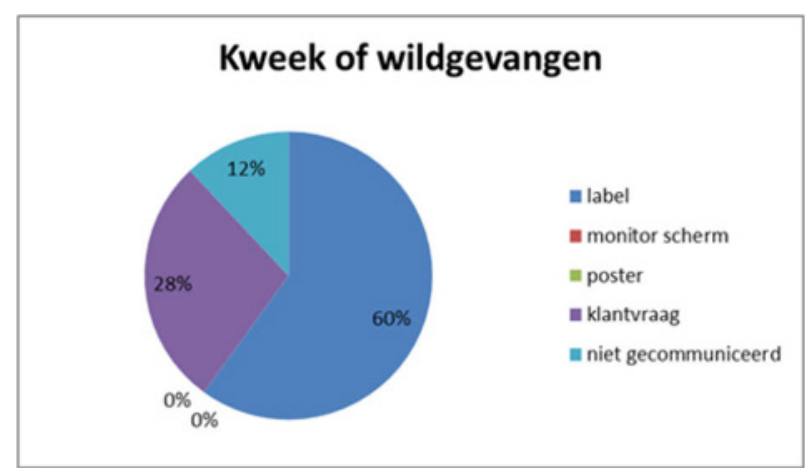

Figur 3.9 Informatiekanalen over kweek of wild gevangen vis.

\section{Allergenen}

Respondenten is gevraagd of en op welke manier zij allergeneninformatie verstrekken bij de vis en visproducten. Vierenveertig procent van de visdetaillisten geeft aan zelf allergeneninformatie te vertrekken via label, monitor of poster. In de meeste gevallen wordt allergenen informatie verstrekt als de klant erom vraagt: het gaat dan om klanten die met een allergie van doen hebben. Een aantal respondenten (meestal met een winkel) geven aan in de zaak een map te hebben liggen met uitgebreide allergeneninformatie per product. Deze informatie is veelal te uitgebreid en specifiek om via een label of anderszins te communiceren. Vooral bij bereide producten zoals vissalades en gebakken vis is allergenen informatie nodig.

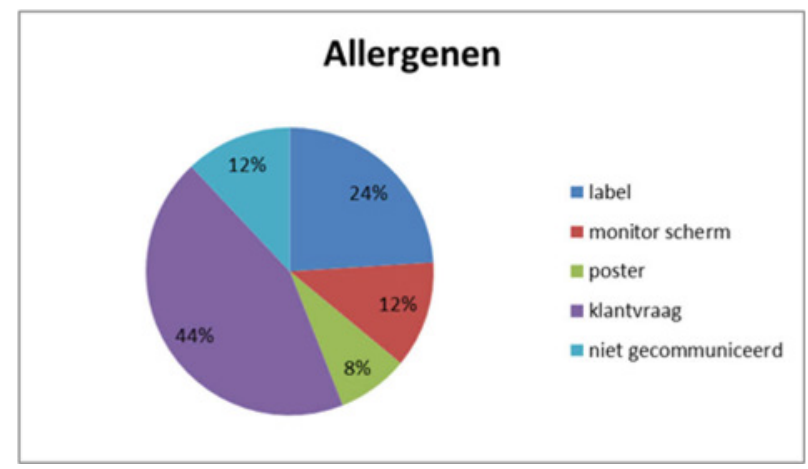

Figuur 3.10 Informatiekanalen over allergenen vis en visproducten.

\section{Duurzaamheidslabel}

Respondenten is gevraagd op welke manier zij bij hun producten aangeven of het MSC of ASC gecertificeerd is. Een kwart van de respondenten geeft aan dit op het label te vermelden en twintig procent vertelt de klant of het product MSC/ASC is als deze erom vraagt. Meer dan de helft van de respondenten geeft aan geen informatie over MSC/ASC te verstrekken. 


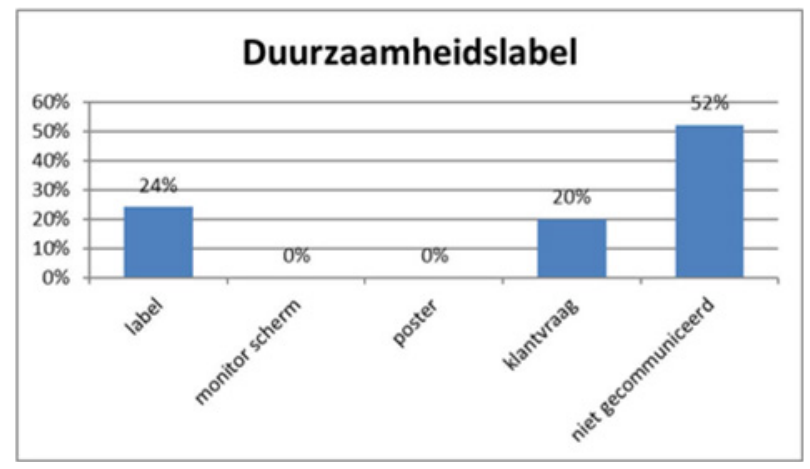

Figuur 3.11 Informatiekanalen duurzaamheid vis.

\subsection{Onverpakte en verpakte vis}

Visdetaillisten verkopen de meeste vis en visproducten onverpakt maar een deel van de producten wordt in de originele verpakking aangeboden. Tijdens de verkenning is gevraagd of visdetaillisten dezelfde informatie verstrekken bij onverpakte en verpakte vis. Voor de enquête is verpakt gedefinieerd als verpakt ingekocht en ongeopend doorverkocht: de vis of het visproduct is niet uit de verpakking geweest, ligt in originele verpakking in vitrine of komt uit de vriezer en wordt zo verkocht aan de consument. Vis die wel door de visdetaillist uit de verpakking wordt gehaald om te portioneren of bereiden (o.a. bakken, eigen gemaakte salades, schoonmaken haring) en in kleinere verpakte of onverpakte eenheden aan de consument aangeboden, valt in de verkenning onder onverpakt (zie vorige paragraaf). Eigen bereidingen zoals salades die door de visdetaillist weer worden verpakt beschouwen we ook als onverpakt.

\section{Prijs}

Tijdens de verkenning is respondenten gevraagd welke informatie zij communiceren bij onverpakte en verpakte vis. Voor zowel onverpakte als verpakte vis geeft het merendeel ( 80 procent) van de respondenten aan de prijs te communiceren.

\section{Latijnse naam}

De Latijnse naam wordt volgens respondenten het vaakst vermeld bij verpakte vis: 70\% geeft aan dat de Latijnse naam op de verpakking van verpakte vis staat terwijl 43 procent van hen aangeeft de Latijnse naam bij de onverpakte vis te vermelden.

Tabel 3.1 Aandeel van de respondenten dat Latijnse naam vermeldt bij onverpakte en verpakte vis.

\begin{tabular}{lll} 
& Onverpakte vis & Verpakte vis \\
\hline Wel vermeld & $43 \%$ & $70 \%$ \\
\hline Niet vermeld & $48 \%$ & $25 \%$ \\
\hline Soms vermeld & $10 \%$ & $5 \%$ \\
\hline
\end{tabular}

\section{Herkomstgebied}

Respondenten geven aan dat het herkomstgebied van de verkochte vis vaker wordt vermeld bij verpakte vis dan bij onverpakte vis. Bij verpakte vis wordt de herkomst veelal op de verpakking aangegeven, bij onverpakte vis moet de detaillist het zelf aangeven. 
Tabel 3.2 Aandeel van de respondenten dat herkomstgebied vermeldt bij onverpakte en verpakte vis.

\begin{tabular}{lll} 
& Onverpakte vis & Verpakte vis \\
\hline Wel vermeld & $61 \%$ & $86 \%$ \\
\hline Niet vermeld & $35 \%$ & $10 \%$ \\
\hline Soms vermeld & $4 \%$ & $5 \%$ \\
\hline
\end{tabular}

\section{Vangstmethode}

Volgens respondenten wordt de vangstmethode in minder dan de helft van de gevallen vermeld. Bij verpakte vis wordt de vangstmethode volgens de visdetaillisten het vaakst vermeld.

Tabel 3.3 Aandeel van de respondenten dat vangstmethode vermeldt bij onverpakte en verpakte vis.

\begin{tabular}{lll}
\hline & Onverpakte vis & Verpakte vis \\
\hline Wel vermeld & $27 \%$ & $45 \%$ \\
\hline Niet vermeld & $64 \%$ & $50 \%$ \\
\hline Soms vermeld & $9 \%$ & $5 \%$
\end{tabular}

\section{Allergenen}

De respondenten geven aan dat allergeneninformatie vaker bij verpakte vis wordt vermeld, veelal staat het al op de verpakking. Een kwart van de respondenten geeft aan allergeneninformatie bij onverpakte vis te vermelden.

Tabel 3.4 Aandeel van de respondenten dat allergenen vermeldt bij onverpakte en verpakte vis.

\begin{tabular}{lll}
\hline & Onverpakte vis & Verpakte vis \\
\hline Wel vermeld & $24 \%$ & $65 \%$ \\
\hline Niet vermeld & $71 \%$ & $20 \%$ \\
\hline Soms vermeld & $5 \%$ & $15 \%$
\end{tabular}

\section{Seizoeninformatie}

Minstens tweederde van de respondenten geeft aan dat seizoeninformatie niet bij de vis wordt vermeld. Seizoeninformatie wordt iets vaker bij onverpakte vis vermeld.

Tabel 3.5 Aandeel van de respondenten dat seizoeninformatie vermeldt bij onverpakte en verpakte vis.

\begin{tabular}{lll}
\hline & Onverpakte vis & Verpakte vis \\
Wel vermeld & $36 \%$ & $29 \%$ \\
\hline Niet vermeld & $64 \%$ & $71 \%$ \\
\hline Soms vermeld & $0 \%$ & $0 \%$
\end{tabular}

\section{Vers of bevroren}

Vis en visproducten worden in verschillende toestanden verkocht: vers, bevroren of ontdooid. Sommige visdetaillisten bieden hun producten met b.v. een lage omloopsnelheid liefst bevroren aan. De respondenten is gevraagd of bij de verpakte en onverpakte vis wordt vermeld of deze bevroren is (geweest). 60\% van de respondenten vermeld bij onverpakte vis dat het product bevroren is of is geweest. Bij verpakte vis gebeurt dat volgens de respondenten veel vaker.

\begin{tabular}{lll}
\hline & Onverpakte vis & Verpakte vis \\
\hline Wel vermeld & $60 \%$ & $83 \%$ \\
\hline Niet vermeld & $40 \%$ & $11 \%$ \\
\hline Soms vermeld & $0 \%$ & $6 \%$
\end{tabular}




\section{Houdbaarheidsdatum}

Volgens de respondenten wordt bij verpakte vis de houdbaarheidsdatum meestal vermeld; deze wordt standaard door de verwerker op de verpakking geplaatst. Tweederde van de respondenten geeft aan dat de houdbaarheidsdatum bij onverpakte vis te vermelden. Veelal wordt deze informatie pas gegeven als de klant erom vraagt en dan in termen van 'vers' of 'vanochtend/gisteren aangevoerd' of de datum die op de verpakking staat, mits deze (nog) voorhanden is.

Tabel 3.7 Aandeel van de respondenten dat houdbaarheidsdatum vermeldt bij onverpakte en verpakte vis.

\begin{tabular}{lll}
\hline & Onverpakte vis & Verpakte vis \\
\hline Wel vermeld & $32 \%$ & $90 \%$ \\
\hline Niet vermeld & $64 \%$ & $5 \%$ \\
\hline Soms vermeld & $5 \%$ & $5 \%$ \\
\hline
\end{tabular}

\section{Kweek of wild gevangen}

De meeste respondenten geven aan dat zowel bij verpakte als onverpakte vis wordt vermeld of de kweekvis is of wild gevangen. Volgens de respondenten wordt dit iets vaker bij verpakte vis gemeld, het staat meestal op de verpakking staat.

Tabel 3.8 Aandeel van de respondenten dat kweek of wild gevangen vermeldt bij onverpakte en verpakte vis.

\begin{tabular}{lll}
\hline & Onverpakte vis & Verpakte vis \\
\hline Wel vermeld & $80 \%$ & $90 \%$ \\
\hline Niet vermeld & $20 \%$ & $10 \%$ \\
\hline Soms vermeld & $0 \%$ & $0 \%$ \\
\hline
\end{tabular}

\section{Vangstdatum}

Het merendeel van de respondenten geeft in de winkel, kraam of bakwagen geen vangstdatum bij de vis wordt vermeld; een kwart van de respondenten geeft aan dat deze wordt vermeld.

Tabel 3.9 Aandeel van de respondenten dat vangstdatum vermeldt bij onverpakte en verpakte vis.

\begin{tabular}{lll} 
& Onverpakte vis & Verpakte vis \\
\hline Wel vermeld & $23 \%$ & $28 \%$ \\
\hline Niet vermeld & $68 \%$ & $56 \%$ \\
\hline Soms vermeld & $9 \%$ & $17 \%$ \\
\hline
\end{tabular}

\section{Duurzaamheidslabel}

Tabel 3.10 Aandeel van de respondenten dat het duurzaamheidslabel vermeldt bij onverpakte en verpakte vis.

\begin{tabular}{lll} 
& Onverpakte vis & Verpakte vis \\
\hline Wel vermeld & $50 \%$ & $75 \%$ \\
\hline Niet vermeld & $40 \%$ & $15 \%$ \\
\hline Soms vermeld & $10 \%$ & $10 \%$ \\
\hline
\end{tabular}

\section{Samenvatting onverpakt-verpakt}

Respondenten geven aan dat bij verpakte vis vaker informatie gegeven over Latijnse naam, herkomstgebied, vangstmethode, allergenen, houdbaarheidsdatum, vangstmethode en duurzaamheid labels dan bij onverpakte vis. 


\section{$4 \quad$ Redenen om wel of niet over duurzaamheid te communiceren}

In het vorige hoofdstuk hebben we kunnen zien wat er wel en niet wordt gecommuniceerd. In dit hoofdstuk richten we ons op de vraag waarom er wel of niet wordt gecommuniceerd over duurzaamheid en door welke type bedrijven. Om hier meer inzicht in te krijgen zijn in fase 2 van het onderzoek diepte-interviews gehouden onder visdetaillisten en -handel en relevante stakeholders. Doel van deze uitgebreide interviews is onduidelijkheden uit de verkenning en achtergronden verder uit te diepen aan de hand van een lijst open vragen. In dit hoofdstuk nemen we de kernpunten die van belang zijn voor dit onderzoek uit het verslag over. De kernvragen uit het onderzoek waren:

1. Hoe verloopt de samenspraak en communicatie tussen visdetaillist, zijn leveranciers en zijn klanten?

2. Welke informatie communiceren visdetaillisten met hun klanten met betrekking tot vis en duurzaamheid?

3. Wat zijn de redenen waarom bepaalde informatie wel met klanten wordt gedeeld en andere niet?

\subsection{Algemene bevindingen}

Drie van de tien ondervraagde visdetaillisten geven aan dat zijn duurzaamheidsinformatie aan hun klanten geven omdat dit een plicht is vanuit de EU-wetgeving en vanuit persoonlijke motief dat men belang hecht aan duurzaamheid. $70 \%$ van de ondervraagde visdetaillisten verstrekt informatie over duurzame vis niet proactief. Als belangrijkste redenen noemen zij dat de meeste klanten geen interesse hebben in achtergrondinformatie over de vis en of hun aankoop duurzame vis betreft. Visdetaillisten redeneren dat hun klanten om deze informatie vragen als ze het willen weten.

\subsubsection{De diversiteit van visdetaillisten is groot}

Er zijn visdetaillisten met een zaak op een vaste locatie (winkel, cafetaria) maar er zijn ook visdetaillisten de vrijwel dagelijks op een andere standplaats staan: o.a. marktkramen en bakwagens. Ook is er sprake zijn van een zekere mate van specialisatie: de een legt zich meer toe op verse vis en de ander op gebakken vis (kibbeling). Ook de locatie van de verkoopplek speelt daarbij een rol. In buurten waar goed verdienende klanten wonen wordt meer luxere verse vis verkocht (Amsterdam Zuid), terwijl in buurten met bewoners uit lagere inkomensklassen klanten minder luxe vis kopen en eerder gebakken vis kopen die ter plekke wordt bereid. Een aandachtspunt voor vervolgonderzoek is of visdetaillisten in buurten met goedverdienende klanten ook meer communiceren over vis en duurzame vis. Met name bij gebakken vis wordt zelden om duurzaamheidsinformatie zoals herkomst of vangstmethode verstrekt of gevraagd.

\subsubsection{Assortiment en omzet worden gedomineerd door verse en gebakken vis}

Het assortiment kan in 3 belangrijke hoofdgroepen worden onderverdeeld: 1. verse vis (inclusief filets en haring), 2. gebakken en gerookte producten en 3. Kant-en-klaar producten zoals salades, pasta en eigen bereidingen. Elke van deze hoofdgroepen kent zijn eigen omzet. De bezochte ondernemers is gevraagd om een inschatting te geven van de verdeling van hun omzet over deze hoofdgroepen. Het grootste deel van de omzet bestaat uit verse en gebakken vis, gemiddeld respectievelijk $40 \%$ en $46 \%$. De verkoop van (vis)salades, verpakte vis en eigen bereidingen vormen een klein deel van de omzet (gemiddeld 15\%). Figuur 4.1 laat zien dat de samenstelling van de omzet tussen individuele visdetaillisten enorm varieert. Sommige bedrijven realiseren $70 \%$ van hun omzet via de verkoop van verse vis terwijl andere bedrijven de hoofdzaak van hun omzet uit de verkoop van gebakken vis genereren. Het blijkt dat de verkoop van gebakken vis een belangrijke inkomstenbron vormt voor bijna de helft van de ondervraagde visdetaillisten. 


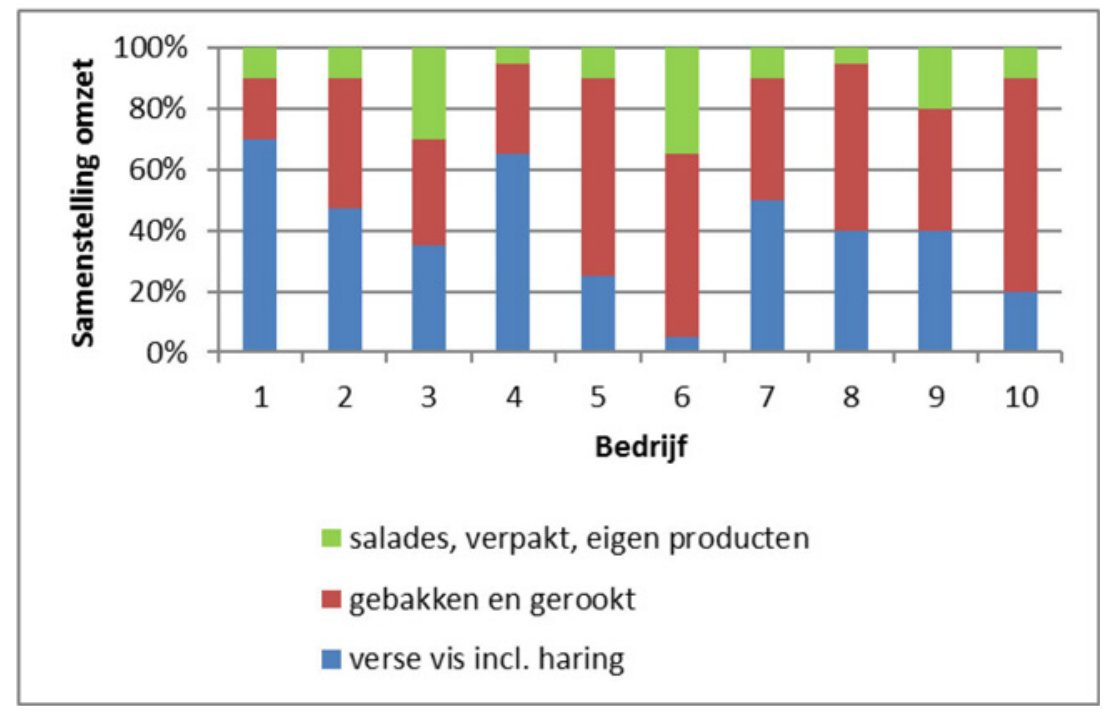

Figuur 4.1 Samenstelling van de omzet van bedrijven van visdetaillisten.

\subsubsection{Gebakken vis is meest geconsumeerde product}

Zestig procent van de ondervraagden van de diepte-interviews geeft aan dat gebakken vis (o.a. kibbeling) hun meest verkochte product is. Enkele van hen hadden hun verkooppunt op een toeristische plaats zoals Volendam. Toeristen willen het liefst typisch Nederlandse producten proeven zoals gebakken vis (kibbeling) en haring. Van de ondervraagden die verse vis verkopen gaven enkelen aan veel verse zalm te verkopen, een duurdere vissoort. Zij hebben hun zaak in buurten met hogere inkomens. Dit geeft de indruk dat de communicatie bij gebakken vis beperkter is.

Visdetaillisten noemen ook andere factoren zoals het seizoen en het maaltijdtype. Bij aanvang van het nieuwe haringseizoen is de haring zeer gewild. Klanten kopen verse zalm of tonijn als ze zelf Sushi gaan bereiden terwijl ze vooral makreel of forel kopen voor op de barbecue (BBQ-seizoen). Visdetaillisten met meerdere verkooppunten onderstrepen dat de samenstelling van de verkopen afhangt van locatie en van de opbouw van de klantenkring. Dit zou kunnen betekenen dat de manier van communicatie per locatie verschillend is en o.a. afhankelijk van de samenstelling van de klantenkring.

Volgens visdetaillisten neemt de vraag naar kant-en-klaar producten toe (salades, pasta, pizza). Vanwege de mooie marge die op deze producten behaald kan worden neigen meer visdetaillisten ertoe om deze gemaksproducten zelf te bereiden. Omdat ze de producten zelf bereiden weten ze precies welke en hoeveel van de ingrediënten in de producten zit en ze kunnen dat exact aan hun klanten vertellen. Visdetaillisten merken dat klanten steeds vaker vragen welke ingrediënten er in een product zitten bijvoorbeeld vanwege allergie. Men kan daarop ook inspelen en product voor de specifieke klant samenstellen. Bovendien hoeft bij eigen bereidingen van kant-en-klaar producten geen informatie met klanten gedeeld te worden zoals voorgeschreven in de EU-labeling regelgeving, en ook geen informatie over duurzaamheid. Dit zou een reden kunnen zijn dat men meer neigt naar eigen bereidingen en het is een manier om regelgeving en discussies over duurzaamheid te omzeilen/vermijden. De exacte redenen dienen nader onderzocht te worden. 


\subsection{Informatie-uitwisseling tussen visdetaillisten en hun leveranciers is geen bottleneck in communicatie naar de consument}

Alle ondervraagde visdetaillisten geven aan bij meer dan één visleverancier vis in te kopen. Visdetaillisten kopen hun vis in op de afslag, bij of via de groothandel of bij visrokerijen. Met deze leveranciers hebben ze een lange termijn relatie. Deze relatie berust op vertrouwen in de leverancier. Er wordt niet snel van leverancier gewisseld. Alle visdetaillisten geven aan dat ze tevreden zijn over de producten die ze ontvangen. De kwaliteit van de vis is daarbij verreweg het belangrijkste. Kwaliteit staat voor vlezigheid en vers, pas gevangen. Deze factoren bepalen samen de goede smaak van vis.

Voor het merendeel (zestig procent) van de ondervraagden is de prijs minder belangrijk zolang de kwaliteit maar perfect is. Voor de overige ondervraagden is de kwaliteit belangrijk maar voor hen telt ook de prijs.

Zoals aangegeven worden drie typen leveranciers onderscheiden wat onder andere samenhangt met de specialisatie van de leveranciers (tabel 4.1):

1. De veiling. Voor de inkoop van verse vis gaan de meeste visdetaillisten zelf naar de afslag om de vis zelf te kunnen beoordelen voordat ze hem kopen. Zodoende heeft men meer controle over het eindproduct dat ze aan hun klanten verkopen. Twee van de ondervraagden kopen verse vis in via de groothandel, de groothandel regelt alles voor hen.

2. Rokerijen. Gerookte vis wordt ingekocht bij visrokerijen. Het roken is een specialisme en het zelf roken van vis in de winkel verre van rendabel.

3. Groothandel. De groothandel levert op bestelling een breed scala aan vis en visproducten variërend van verse vis, diepgevroren en kant-en-klaar producten.

Tabel 4.1

Overzicht van type leverancier, producten en gebruik

\begin{tabular}{lll}
\hline Type leverancier & Aangeboden product & Gebruikt in productgroep \\
\hline Rokerij & Gerookte vis & Gerookte vis en kant en klaar producten \\
\hline Afslag & Verse onbewerkte vis & Verse vis en gebakken vis \\
\hline Groothandel & $\begin{array}{l}\text { Verse vis (inclusief haring), filets, } \\
\text { ingevroren en kant-en-klaar producten }\end{array}$ & $\begin{array}{l}\text { Verse vis, gebakken vis en kant en klaar } \\
\text { producten }\end{array}$ \\
\hline
\end{tabular}

\subsubsection{Informatie-uitwisseling tussen leveranciers en visdetaillisten}

Op het moment dat visdetaillisten vis van hun leverancier kopen is informatie beschikbaar maar in welke vorm en hoe informatie wordt uitgewisseld hangt af van de leverancier. Ook de manier waarop informatie-uitwisseling plaats vindt varieert: schriftelijk, mondeling of per mail.

\section{Schriftelijke informatie-uitwisseling}

De uitwisseling van vastgelegde informatie vindt plaats via papieren rekeningen of digitaal (email), afslagbrieven die bij de levering zitten of stickers op de verpakking. Deze leveranciersdocumenten bevatten soms beperkte informatie zoals vissoort, hoeveelheid en prijs. Leveranciers verstrekken soms geen extra informatie over bijvoorbeeld vangstgebied, seizoenvis of vangstmethode tenzij visdetaillisten er hun leverancier om vragen. Het merendeel $(70 \%)$ van de ondervraagden geeft echter aan dat hun leverancier bij de rekening, afslagbrief of sticker voldoende aanvullende informatie verstrekt, inclusief de duurzaamheidsinformatie over herkomst van de vis (vangstgebied), seizoen en vangstgebied. Op de afslag kan de koper de afslagdocumenten voor de koop inzien als hij rondloopt en de vis beoordeelt en zich vergewist van de duurzaamheidsinformatie.

Naarmate de digitalisering op afslagen verder zal worden ingevoerd, wordt online bieden en informatie-uitwisseling nog gemakkelijker. Zo kunnen er voor de afslag tegenwoordig online biedingen van huis uit worden gedaan; ook kunnen visdetaillisten op hetzelfde moment meedoen aan meerdere biedingen. Dit leidt ertoe dat goede kwaliteit vis voor een juiste prijs wordt ingekocht. Nadeel is dat 
men niet meer rondloopt over de afslag om de kwaliteit van de aangeboden vis zelf te kunnen beoordelen. In plaats daarvan moet de visdetaillist (kunnen) vertrouwen op het digitale kwaliteitslabel dat per vissoort wordt verstrekt.

\section{Vrijwillige informatie-uitwisseling}

Naast de schriftelijke informatievoorziening hebben visdetaillisten altijd de mogelijkheid om hun leveranciers om aanvullende informatie te vragen. De vraag om extra informatie berust vaak op persoonlijke interesse van de visdetaillist of een klantvraag. In alle gevallen probeert de leverancier als het mogelijk is deze extra informatie te verstrekken. Van de ondervraagde visdetaillisten geeft de helft aan zelden of nooit om extra duurzaamheidsinformatie te vragen. Sommige visdetaillisten beweren dat ze met hun lange ervaring in de vis aan de hand van karakteristieken van de vis (o.a. kleur, uiterlijk) kunnen beoordelen waar deze vis is gevangen.

Tijdens de interviews is ook met een visdetaillist gesproken die bij inkoop om specifieke duurzaamheidsinformatie vraagt vanuit zijn eigen overtuiging om als visdetaillist kritisch te zijn met het oog op de toekomst van de visserij. Deze ondernemer focust op de verkoop van duurzame vis en wil bij voorkeur vis van het seizoen en gevangen met specifieke vistuigen (long line en staand net vanwege het geringe volume aan bijvangst)

\section{Voldoende standaard- en duurzaamheidsinformatie beschikbaar}

Samenvattend kan geconcludeerd worden dat de meeste visdetaillisten vinden dat ze voldoende standaard- en duurzaamheidsinformatie ontvangen (soort, hoeveelheid en prijs) en geen aanvullende informatie opvragen. Daarnaast geven de ondervraagde visdetaillisten aan dat hun leveranciers elke vraag om specifieke informatie zoals vangsttechniek of gebied van oorsprong kunnen beantwoorden. Visdetaillisten kunnen in principe alle informatie van hun leveranciers krijgen in het geval hun klanten daar om vragen. Kortom, de verstrekking van de informatie vanuit de leverancier vormt geen bottleneck in de uiteindelijke communicatie: de informatie is er wel.

\section{Kennis over de aangekochte vis}

Visdetaillisten is gevraagd of zij de verstrekte informatie die zij over veel verkochte producten ontvangen, ook kunnen interpreteren. De meeste visdetaillisten hebben voldoende kennis over de vis en visproducten die ze verkopen zoals de herkomst van de vis. Ook weten visdetaillisten het seizoen van de vissoort. Zo wordt schol niet in december tot en met februari verkocht vanwege de lage vlezigheid/gewicht.

\subsection{Informatie-uitwisseling tussen visdetaillisten en hun klanten}

Bij de communicatie tussen visdetaillist en zijn klanten zijn de kennis over de EU-labelling en wat daarover door de visdetaillist met klanten wordt gecommuniceerd. Het gaat dan om:

- Kennis over EU labeling en wat daarover met consumenten wordt gedeeld;

- De communicatiekanalen;

- Wat vindt de visdetaillist belangrijk en onbelangrijk bij de communicatie over certificering (Nr. 1169/2011).

Alle ondervraagde visdetaillisten geven aan dat ze van het bestaan van de EU-etiketteringswetgeving (EU-consumentenetikettering van visserij- en aquacultuurproducten) voor op de hoogte zijn. Van de tien ondervraagden geven er twee invulling aan de voorschriften uit de EU-etiketteringswetgeving. Echter, om het doel dat duurzaamheid en transparantie binnen de visketen gemeengoed worden, moet een situatie gecreëerd worden dat elke visdetaillist de wettelijke voorschriften volgt. Om dat te verwezenlijken is het van belang de mening van visdetaillisten over deze wetgeving te kennen. In de 
interviews geven enkele visdetaillisten aan dat deze wetgeving niet is afgestemd op de praktische gang van zaken in viswinkels en marktkramen. Niet alle informatie is relevant als je naar duurzaamheid kijkt. Als voorbeeld noemen ze het vermelden van de Latijnse naam. Het vermelden van veel informatie op labels bij de vis in de vitrine maakt dat deze labels onleesbaar worden, waardoor deze informatie ook niet door klanten wordt gelezen. Bovendien merken visdetaillisten dat er geen enkele controle is op de opvolging van de regelgeving. Dat geeft bij geen van hen de druk dat het noodzakelijk is om invulling te geven aan de wettelijke voorschriften.

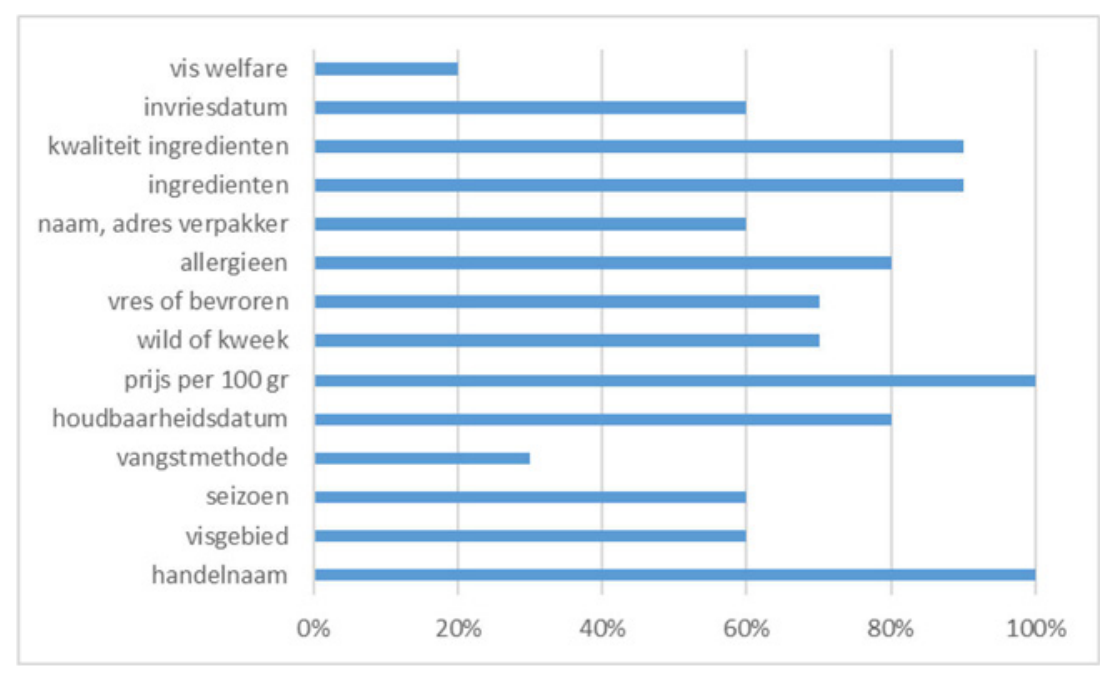

Figuur 4.2 Aandeel visdetaillisten dat informatie uitwisselt over duurzaamheid.

Een groter deel van de visdetaillisten zou de wettelijk voorschriften opvolgen als deze beter wordt aangereikt.

\section{Communicatie met klanten}

Uit de enquête en de interviews blijkt dat visdetaillisten meerdere informatiekanalen gebruiken om hun klanten te informeren. Figuur 4.3 geeft een overzicht welke communicatiekanalen visdetaillisten het meest gebruiken.

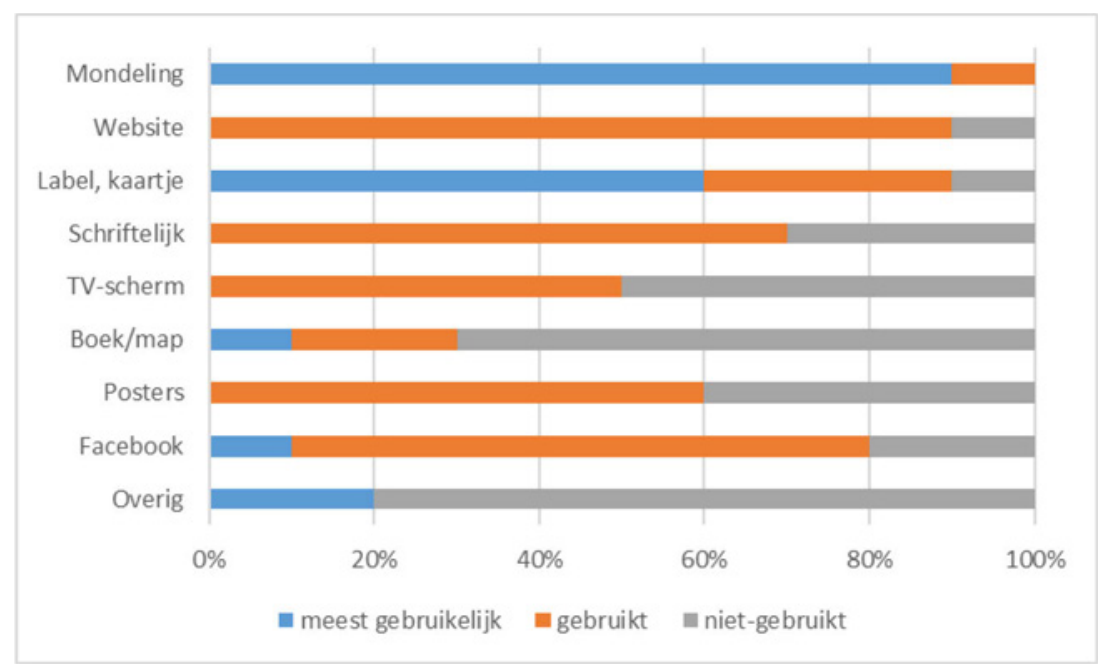

Figuur 4.3 Gebruik van communicatiekanalen (percentage van de visdetaillisten). 
Visdetaillisten geven aan dat mondelinge communicatie en het label/kaartje bij de vis in de vitrine de meest gebruikte manieren zijn om met hun klanten te communiceren.

Alle bedrijven communiceren mondeling met hun klanten (face-to-face), waarbij één bedrijf dit als strategie hanteert en bewust geen andere communicatiekanalen gebruikt. Face-to-face is eenvoudig en de beste manier om vertrouwen met klanten op te bouwen resulterend in een lange termijn relatie.

De vermelding 'wij kopen zelf op de visafslag in' associëren consumenten met het feit dat de visdetaillist direct contact heeft met de visser.

Eigenaren van winkels en kiosken gebruiken meerdere communicatiekanalen en zijn actiever op internet dan eigenaren van marktkramen. De informatievoorziening via internet betreft hoofdzakelijk de informatie via een eigen website en Facebook (aanbiedingen en visschotels). Een van de ondervraagde visdetaillisten exploiteert ook een webshop. Visdetaillisten signaleren een trend dat voedsel en ook vis steeds vaker via webshops wordt besteld.

Op de labels/ kaartje bij verse vis en visproducten vermelden alle bedrijven handelsnaam, bedrijfslogo en de prijs per 100 gram. Bij verpakte vis staat alle informatie op de verpakking. Het vermelden van extra aanvullende informatie op labels per vissoort zoals vangstgebied, vangsttechniek, seizoen, etc. vergt extra inspanning om deze informatie op het kaartje te schrijven én voortdurend actueel te houden. Zoals eerder aangegeven is het kaartje veel te klein voor zo veel informatie.

\section{De VISwijzer}

Een niet genoemd kanaal voor de uitwisseling van duurzaamheidsinformatie is de Viswijzer die is ontwikkeld door de Stichting Noordzee en later is overgenomen door de Good Fish Foundation. Bijna alle geïnterviewde visdetaillisten kennen de viswijzer, echter maar twee van hen geven aan de Viswijzer te gebruiken en het een handig hulpmiddel te vinden. Deze twee gebruikers geven wel aan dat het hen tijd heeft gekost om de Viswijzer te doorgronden. Vier visdetaillisten geven aan dat ze de Viswijzer als een handig hulpmiddel zien, maar ze gebruiken hem niet.

Enkele visdetaillisten hebben kleine problemen met de Viswijzer omdat deze vissoorten bevat die niet via de Viswijzer gepromoot zouden moeten worden. Dit geldt met name voor Pangasius die volgens de visdetaillisten een van de meest vervuilende en ongezondste vissoorten is als je kijkt naar antibioticagebruik. Bovendien vervuilt de output van Pangasius de rivieren en uiteindelijk de zee. De betreffende visdetaillisten verkopen daarom zelf geen Pangasius.

Zeventig procent van de ondervraagde visdetaillisten geeft aan dat ze nooit hebben waargenomen dat hun klanten de VISwijzer gebruiken. De meeste van hen denken dat de Viswijzer mogelijk te complex is. Eén visdetaillist gaf aan dat de meeste klanten de Viswijzer niet kennen en nauwelijks bezig zijn met en aandacht hebben voor de duurzaamheid van vis.

\section{De betekenis van duurzaamheid voor visdetaillisten}

Gevraagd is wat visdetaillisten zelf vinden van duurzaamheid. Tijdens de gesprekken bleek dat visdetaillisten duurzaamheid vooral linken met milieu en met name met de ecologie. Ze herkennen dat bepaalde aspecten van de EU-labeling-regelgeving naar duurzaamheid verwijst: vissoort en herkomst staat in relatie met kwetsbaarheid, vistechnieken hebben een relatie met bijvangst en vernietiging van het leefgebied van de vis en seizoen vis relateert men met de totale vangst en overbevissing. Kortom visdetaillisten linken duurzaamheid op verschillende manieren aan het milieu.

In de meeste gevallen interpreteren visdetaillisten duurzaamheid als 'kijken in de toekomst'. In dat verband zijn de huidige milieukundige invloeden zeer belangrijk: ze grijpen in op de toekomst van de visserij-industrie. De teneur onder de visdetaillisten is dat de visserijsector moet toewerken naar een situatie dat ook toekomstige generaties in de visserij werkzaam kunnen blijven.

Tijdens de interviews over duurzaamheid brachten visdetaillisten ook de problemen van de visserij naar voren:

- Alle visdetaillisten zien overbevissing als een van de belangrijkste bedreigingen. 
- Een $100 \%$ duurzame visserijsector is volgens de ondervraagden een vrijwel onmogelijke opgave. Zeker als de prijs van de vis leidend is zijn consumenten weinig kritisch op het moment dat ze vis kopen. Zolang een heldere strategie en actieplan ontbreken zijn consumenten en actoren niet bereidt extra te betalen voor duurzame vis. Wel erkennen de ondervraagde visdetaillisten dat het niet eenvoudig is een heldere strategie en actieplan te formuleren.

"Het meest moeilijk is om een perfecte balans tussen people, planet en profit creëren. Bovendien is het onmogelijk om te voorspellen hoe de natuur zal reageren, zelfs als het idee er is hoe het uitpakt. Vaak ontstaan onverwachte problemen. De enige manier waarop vispopulaties zich kunnen herstellen is om ze gedurende aan lange periode volledig ongemoeid te laten. Maar omdat visserij voor veel mensen de enige inkomstenbron is, is dit 'niet vissen' geen optie. Er moet een alternatief komen"

De ondervraagde visdetaillisten noemden ook met oplossingen voor de huidige duurzaamheidsproblemen:

- Volgens de meesten is de beste oplossing om alleen 'vis van het seizoen' te verkopen. Dit beschermt de visvoorraad, de kwaliteit van de verkochte vis en op lange termijn de toekomst van de sector. Dit is de eerste stap, maar visdetaillisten erkennen dat ook zaken als vangsttechniek en vangstgebied aangepast moeten worden.

- De regelgeving met betrekking tot bijvangst moet aangepast worden voor specifieke soorten in plaats van deze generiek toe te passen voor alle soorten. Onderzocht dient te worden welke soorten wel en welke niet overleven als ze worden teruggegooid. Als ze toch dood gaan kunnen ze beter worden aangevoerd. Volgens visdetaillisten overleeft bijvoorbeeld jonge aal en is het logisch deze terug te gooien.

- Quota voor alle vissoorten. Quota worden gebaseerd op de kwetsbaarheid van per vissoort. De quota kunnen gekoppeld worden aan 'vis van het seizoen'.

- Plastic moet uit de zee en verboden worden;

- Duurzaamheid wordt ook in verband gebracht met voedselverspilling: gooi geen eten weg;

- Er moet een oplossing komen voor het gebruik visolie en vismeel in de viskweekindustrie en aquacultuursector. Om vis te kweken is twee keer zoveel vis nodig voor de productie van olie en meel. Dit zet bovendien druk op de toch al overbeviste visvoorraden.

Visdetaillisten geven hier mee aan duurzaamheid bredere te zien en dat certificatie in de vishandel niet alle geschetste zaken oplost.

\section{De betekenis van certificatie voor visdetaillisten}

Certificering zoals MSC en ASC kan volgens een aantal geïnterviewden gezien worden als een marketing instrument waarmee de keuze voor duurzame vis voor consumenten eenvoudiger wordt. In deze paragraaf kijken we hoe visdetaillisten aankijken tegen certificering:

- Wat vinden visdetaillisten van certificering?

- Kopen visdetaillisten gecertificeerde vis in en zo ja betreft dit het hele of een deel van het assortiment?

- Communiceren zij met hun klanten over ingekochte gecertificeerde vis?

Figuur 4.4 toont hoe visdetaillisten tegen certificering aankijken. 


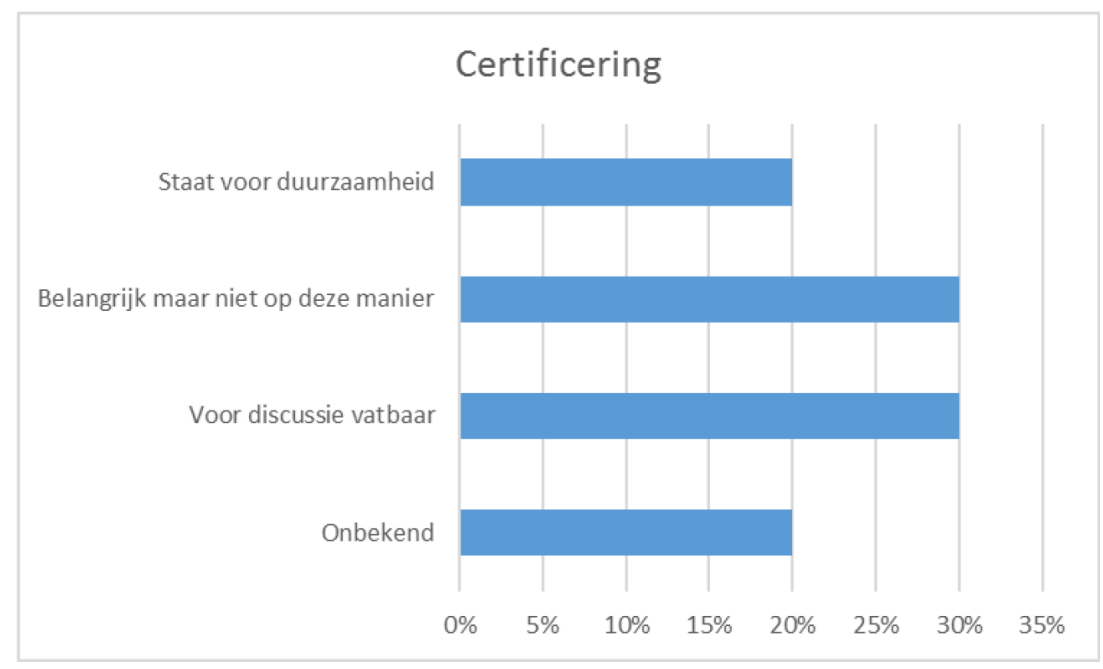

Figuur 4.4 Mening van visdetaillisten met betrekking tot certificering (\% ondervraagde visdetaillisten).

Volgens enkele visdetaillisten staat certificering (zoals MSC, ASC) voor duurzame vis. Het merendeel van de ondervraagde visdetaillisten hebben daar vraagtekens bij om de volgende redenen:

- Certificering vormt geen garantie dat alle vis altijd van duurzaam is.

- Ondernemers (in de visketen) gebruiken certificering om wat ze doen te rechtvaardigen zoals volgens enkele visdetaillisten bij haring gebeurt. Promoten dat je duurzame haring (MSC) verkoopt, vormt nog geen garantie dat de gehele haringketen duurzaam te werk gaat.

- Eén visdetaillist heeft twijfels over het verhaal bij MSC-kabeljauw. Voor deze visdetaillist betekent duurzaamheid dat gelet wordt op de gevangen hoeveelheid vis, de omvang van de populatie en de relatie daartussen. Hij betwijfelt of grote schepen die gedurende maanden grote hoeveelheden kabeljauw vangen met deze relatie rekening houden en heeft daarom twijfels over het MSC-label.

\section{Inkoop van vis: duurzaam of niet?}

Kortom visdetaillisten hebben hun twijfels over certificering en de vraag is of deze twijfels invloed hebben als zij gecertificeerde vis in- en verkopen.

Eén van de tien ondervraagde visdetaillisten koopt enkel gecertificeerde vis in; de overige visdetaillisten (90\%) kopen en verkopen zowel gecertificeerde als niet-gecertificeerde vis. De redenen waarom visdetaillisten gecertificeerde vis inkopen is dat sommige vissoorten enkel gecertificeerd worden aangeboden (bijvoorbeeld haring) of dat de gecertificeerde vis een betere kwaliteit heeft. De visdetaillist die enkel gecertificeerde vis koopt geeft aan: de enige manier om altijd gecertificeerde vis in te kopen is om met een kleiner assortiment te werken. De beide visdetaillisten die aangaven dat certificering voor duurzame vis staat, hebben hun eigen redenen om niet alle vis duurzaam in te kopen. Niet alle vis wordt namelijk gecertificeerd aangeboden, met name als het gaat om vis van het seizoen. Bovendien vinden zij dat dat het belangrijk is te weten dat niet alle duurzame vis altijd gecertificeerd is. Dit betreft onder andere de vis die gevangen wordt door kleine vissers die wel duurzame vismethoden gebruiken maar niet in staat zijn de kosten van certificering te dragen.

\section{Communicatie over certificering tussen visdetaillisten en hun klanten}

Gevraagd is of en hoe visdetaillisten actief met hun klanten communiceren over certificering. De communicatie over gecertificeerde vis vindt plaats door een logo van het certificaat op het kaartje bij de vis aan te brengen of bijvoorbeeld via een etiket.

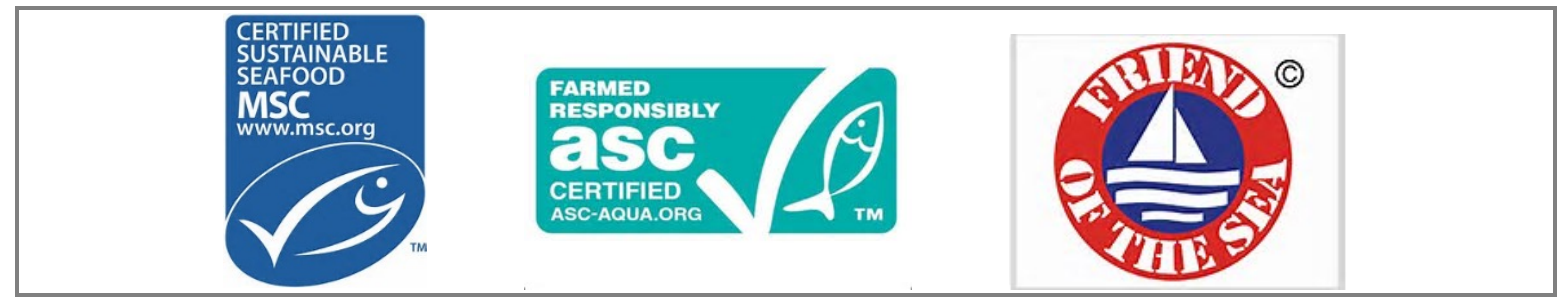

Figuur 4.5 Logo's MSC, ASC en Friend on the Sea

32 | Communicatie over duurzame vis in de visdetailhandel 
In geval van mondelinge communicatie over het gecertificeerde product moeten klanten erop kunnen vertrouwen dat de visdetaillist de waarheid vertelt. Het grootste deel van de ondervraagde visdetaillisten $(60 \%)$ communiceert niet actief over certificering met hun klanten omdat klanten er niet om vragen. Eén visdetaillist merkt in dit verband op: 'Als visdetaillisten niet actief met hun klanten over certificering communiceren dan ontstaat er ook geen aandacht voor: stilstand is achteruitgang'. Maar in geval klanten er om vragen zal een visdetaillisten naar eer en geweten een eerlijk antwoord geven of de betreffende vis wel of niet gecertificeerd is.

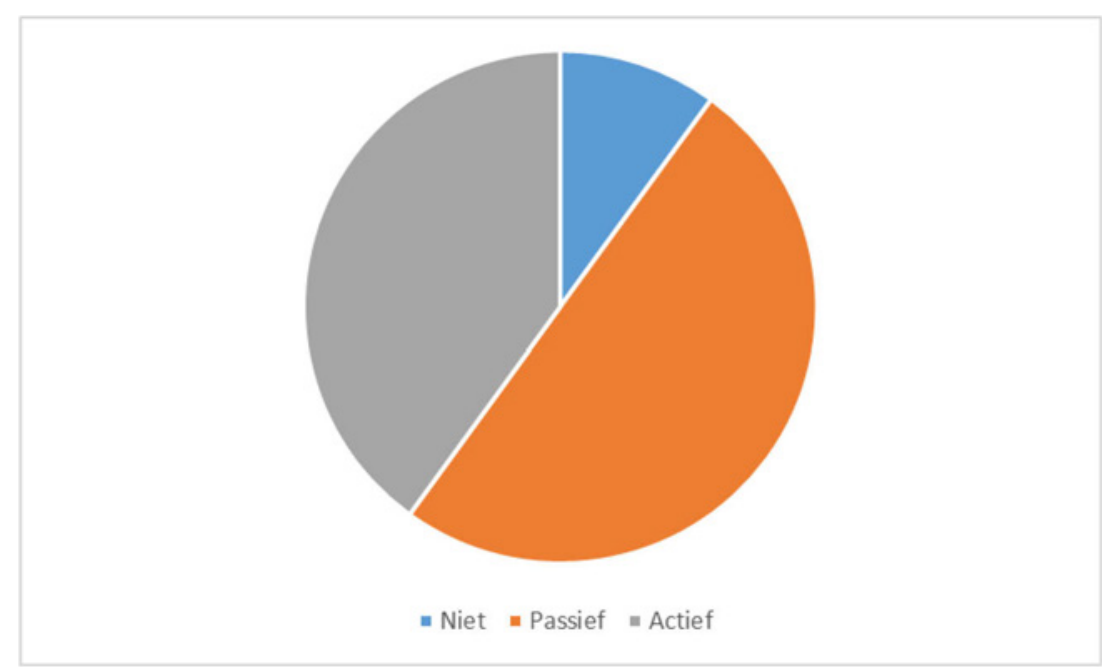

Figuur 4.6 Communicatie over gecertificeerde vis door visdetaillist naar klanten (\% visdetaillisten).

Veertig procent van de visdetaillisten geeft aan actief over certificeerde vis te communiceren. In deze groep zitten ook de beide visdetaillisten die vanuit eigen overtuiging actief over duurzame vis communiceren; zij geloven dat de duurzame visserij van het grootste belang is voor de toekomst van de vis. Deze beide visdetaillisten merken daarbij op dat hun klanten meer interesse (gaan) tonen in de achtergronden van duurzame vis en deze ook vaker kopen/consumeren. Deze beide visdetaillisten gaan ook het logo op de kaartjes bij de vis plaatsen omdat ze erin geloven dat certificering tot een betere toekomst leidt en ze merken dat klanten geïnteresseerd zijn en er vragen over gaan stellen. De twee andere actieve communicerende visdetaillisten verkopen een klein deel van hun assortiment als duurzame vis; bij hen staat het logo al op de verpakking van de vis. Ook deze visdetaillisten zien dat hun klanten meer interesse tonen in duurzame vis. Een van hen verkoopt alleen gerookte paling met het DUPAN-logo (Stichting Duurzame Palingsector Nederland). De ander die een kleine hoeveelheid duurzame vis verkoopt, gelooft dat Geelvintonijn van 'Friend of the Sea' momenteel de meest duurzame gecertificeerde tonijnsoort is. Deze detaillist merkt op: 'Als ik écht een statement wil maken zou ik geen tonijn verkopen. Echter, dat is onmogelijk want als je bepaalde producten zoals tonijn niet verkoopt, gaan klanten naar een ander'. Dit wordt door de andere visdetaillisten bevestigd: als bepaalde visproducten in je assortiment ontbreken gaan klanten naar een ander. De producten die een viswinkelier sowieso altijd moet hebben zijn: tonijn, zalm, verse kabeljauw en haring.

Ook waren slechts 4 visdetaillisten bekend met het feit dat men zelf als bedrijf gecertificeerd moet zijn of bepaalde richtlijnen moet volgen om het logo te mogen voeren en gecertificeerde vis te kunnen verkopen; daarvoor heeft het bedrijf erkenning en toestemming van de certificeringsorganisatie zoals MSC nodig. Een van de visdetaillisten zet om die reden in plaats van het logo op het label de omschrijving 'duurzaam gevangen vis'. Een groot deel van de visdetaillisten geeft aan niet op de hoogte te zijn dat men gecertificeerd moet zijn om gecertificeerde vis te mogen verkopen.

Desondanks is geen van hen van plan om gecertificeerd te worden omdat:

1. Het verkrijgen van certificering duur is, met hoge kosten gepaard gaat;

2. Het voor kleine bedrijven zoals visspeciaalzaken lastig is om de investering en kosten voor duurzaamheid terug te verdienen terwijl de vraag naar gecertificeerde vis klein is: klanten vragen niet of zelden om duurzame vis. 
'Als er in mijn zaak twee keer per week om duurzame vis wordt gevraagd is het vaak'

Volgens de visdetaillisten bevoordeelt de huidige certificeringsystematiek, zoals MSC, de supermarkten en is daarom een oneerlijk systeem. Voor het verkrijgen van de certificering werken supermarkten samen waardoor ze in staat zijn de kosten per verkooppunt/bedrijf laag te houden.

'Als visdetaillisten zouden samenwerken voor het verkrijgen van MSC-certificering zouden de kosten veel lager zijn. Maar dat is moeilijk omdat elke visdetaillist op zijn eigen eilandje zit en met zijn eigen dingen bezig is. Supermarkten werken samen. Dat is de belangrijkste reden waarom zij alle vis MSCgecertificeerd verkopen'.

\subsection{Redenen om wel/geen informatie te delen vanuit de perceptie van de visdetaillist}

Volgens krantenberichten komen klanten naar de viswinkel/kraam vanwege de kwaliteit en omdat ze verse vis willen. De visdetaillisten is gevraagd wat voor hen de belangrijkste redenen zijn om wel of geen informatie met hun klanten te delen, wat hun klanten van vis weten en welke criteria klanten hanteren bij de aankoop van vis.

\subsubsection{Visdetaillisten over hun klanten}

Tot nu toe is gekeken wat visdetaillisten vinden van en communiceren over de regels van de EUlabeling, de duurzaamheid en certificering. Tijdens de interviews is ook geïnformeerd wat visdetaillisten over hun klanten weten en kunnen vertellen. Visdetaillisten geven aan dat ze niet alle beschikbare informatie (inclusief duurzaamheidsinfo) met hun klanten delen of communiceren omdat klanten daar geen interesse in hebben. De meeste visdetaillisten geven aan dat klanten zelden vragen om achtergrondinformatie of duurzaamheidsaspecten van de vis(soorten). Wat klanten wel belangrijk vinden wordt geïllustreerd in figuur 4.7.

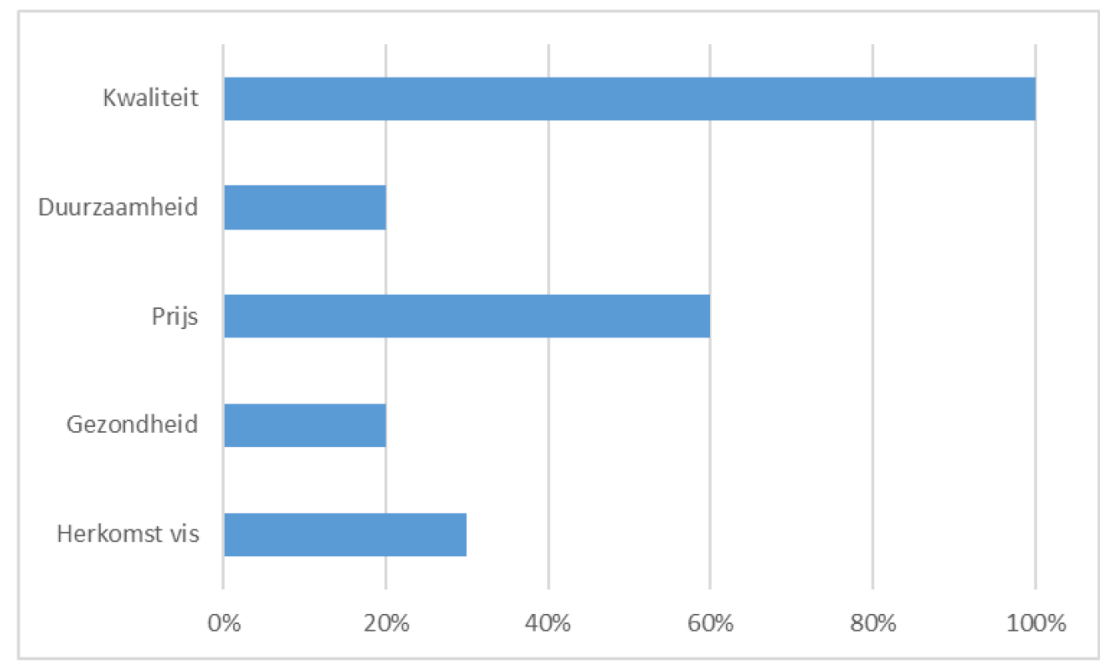

Figuur 4.7 Aspecten die klanten volgens visdetaillisten belangrijk vinden bij de aankoop van vis in visdetailzaken (\%visdetaillisten). 
Visdetaillisten geven aan dat bepaalde aspecten belangrijker zijn geworden onder invloed van de voorlichting over voeding en kookprogramma's die 'vis is gezond' onder de aandacht brengen. Volgens visdetaillisten is kwaliteit (en vers) een van de belangrijkste aankoopcriteria voor hun klanten, vaak in combinatie met prijs. Een beperkt deel van de visdetaillisten noemt ook 'gezondheid' als aankoopcriterium. Herkomst van de vis kan ook met duurzaamheid te maken hebben, bijvoorbeeld als consumenten bewust kiezen voor 'vis van dichtbij'.

Visdetaillisten beschouwen de kinderen van vis kopende ouders als hun toekomstige klanten. Ze hopen dat deze kinderen in de toekomst ook naar de visspeciaalzaak komen en niet naar de supermarkt gaan en zich later de goede kwaliteitsvis die hun ouders kochten en met hen consumeerden, blijven herinneren als heerlijke vis. Een paar visdetaillisten noemden dat hun klanten gezondheid en duurzaamheid veel belangrijker vinden dan de prijs.

Volgens visdetaillisten zijn hun klanten eerder bereid meer te betalen voor een betere kwaliteit dan voor duurzame vis. Waarbij goede kwaliteit niet vanzelfsprekend staat voor duurzame vis. Een van de respondenten geeft aan dat klanten niet weten wat duurzame vis exact inhoudt omdat ze zo veel gemengde informatie krijgen, wat leidt tot verwarring. Dit kan een belangrijke reden zijn waarom het grootste deel van de klanten zich niet over duurzaamheid bekommert: ze weten niet waar het om gaat en wat ze erover moeten vragen. Echter om dit te bevestigen is diepgaander onderzoek onder klanten/consumenten nodig.

Op het moment dat iets te gecompliceerd wordt, kijken veel visdetaillisten en klanten naar de andere kant. Dit is waar te nemen als het gaat om duurzaamheid, inclusief certificering en de Viswijzer.

Organisatie vertellen verschillende verhalen en zeggen verschillende dingen. Voor de visdetaillisten en hun klanten lijkt het op die manier op het zoeken naar een speld in een hooiberg.

\subsubsection{Redenen om wel/niet actief te communiceren over vis en duurzaamheid}

Van de ondervraagde visdetaillisten communiceren vier proactief. Ze doen dat vooral vanuit hun persoonlijke overtuiging. Echter de motivatie waarom ze dit doen verschilt, namelijk:

- Vanwege de EU-regelgeving (wettelijke plicht)

- Eigen overtuiging en persoonlijke motivatie dat duurzaamheid het belangrijkste is voor het voortbestaan van de vispopulatie en ecosystemen wereldwijd. Vanuit deze eigen overtuiging communiceert een van de ondervraagde visdetaillisten alle informatie die is voorgeschreven in de EU-labeling law. Zo weet deze detaillist klanten te overtuigen, te enthousiasmeren en gepassioneerd te laten raken over vis en duurzaamheid.

- Het resultaat is dat de klanten van deze detaillisten meer geïnteresseerd raken in vis en in toenemende mate duurzame vis gaan kopen.

Een van de visdetaillisten ontvangt van zijn leverancier enkel de naam van de vis, de hoeveelheid en prijs. Deze detaillist gaat zelf actief op zoek naar aanvullende informatie die hij opvraagt bij zijn leverancier. Het vangstgebied wordt ook achterhaald op basis van fysieke karakteristieken van de vis en de Latijnse naam wordt op internet opgezocht. Deze visdetaillist deelt ook alle informatie met de klanten vanuit de eigen overtuiging dat alles wat de wet voorschrijft met klanten gedeeld moet worden. Als de wet er niet zou zijn, zou deze persoon niet communiceren over de vis en duurzaamheid. De beide andere visdetaillisten ontvangen de aanvullende informatie op papier van hun leverancier.

Een visdetaillist merkt op: "De consumptie van vis is de laatste jaren toegenomen door de promotiecampagne dat het eten van vis gezond is. Tegelijkertijd ontstaat discussie over de verantwoordelijkheid voor een duurzame visserijsector omdat de omvang van visbestanden en ecosystemen onder druk staat. Deze druk wordt groter als de vraag naar vis toeneemt. Dus als duurzaamheid in de toekomst geen hogere prioriteit krijgt, dan worden de problemen nog groter en gaan banen in de visserijsector verdwijnen". ... "We moeten onze klanten voorlichten over duurzaamheid, vooral degene die hun informatie alleen via internet vergaren en niets van duurzaamheid begrijpen". 
Zes visdetaillisten geven aan dat ze niet proactief met hun klanten over vis en duurzaamheid communiceren omdat klanten er niet om vragen. $\mathrm{Er}$ is volgens deze detaillisten dus eenvoudigweg geen reden om actief te gaan communiceren.

"Waarom zouden we communiceren als de klanten er niet om vragen? Voor ons heeft dat geen enkel nut." Een ander merkt op: "Het is luiheid om niet actief te communiceren: waarom zou je als klanten er niet om vragen en waarom zou je ze wijzer maken dan ze al zijn."

Tegelijkertijd geven deze visdetaillisten aan dat ze geen tijd hebben om het hele achtergrondverhaal over duurzame vis en bijkomende informatie aan elke klant te vertellen. Klanten moeten dan aanzienlijk langer op hun beurt wachten en daar hebben ze eenvoudigweg geen geduld voor. Omdat de klant koning is past de handel de communicatie daaraan aan.

Een visdetaillist vertelt: "Als je al je hele leven in de vis werkt zie je vis niet meer als vis, maar als een verkoopproduct".

Andere punten die genoemd zijn als het gaat om het wel of niet actief communiceren:

- Een actueel onderwerp onder klanten zijn allergenen omdat deze rechtstreeks invloed hebben op de persoonlijke gezondheid. Zodra iets betrekking heeft op gezondheid en persoonlijke risico's dan leggen klanten sneller associaties. De redenering zou verder uitgezocht moeten worden.

- Vanwege het feit dat maar een gering aantal klanten om uitgebreide informatie vraagt, voelen visdetaillisten geen noodzaak om aanvullende informatie te verstrekken inclusief duurzaamheid. Zelfs als de grote meerderheid van de visdetaillisten deze informatie van hun leveranciers ontvangt.

- De reden dat klanten niet om informatie over duurzame vis vragen zou kunnen zijn dat ze nauwelijks associaties met vis hebben en daarom geen zorgen over duurzaamheid. Dit zou verder uitgezocht moeten worden.

- Een meerderheid van de visdetaillisten denkt niet dat certificering voor duurzaamheid staat of men vindt dat het goed is dat certificering er is maar niet zoals het nu is georganiseerd. Sommige visdetaillisten weten niet altijd wat duurzaamheid exact inhoud of wanneer het om echt duurzame vis gaat. Voor het voeren van het MSC-logo in de winkel of MSC te promoten, moet de visdetaillist gecertificeerd zijn. Er zijn echter meerdere redenen waarom visdetaillisten niet actief over certificering communiceren en een logo hebben. Om zo'n certificaat te verkrijgen moeten hoge kosten gemaakt worden in vergelijking met de omzet die per gecertificeerd product wordt behaald. Daarbij komt de geringe interesse en beperkte vraag van klanten naar gecertificeerde producten en het beperkte aantal vissoorten dat gecertificeerd wordt. Voor het voeren van het ASC of andere logo's gelden dezelfde argumenten.

- Om alle verplichte informatie op het kleine label te plaatsen is niet realistisch en onhandig. Het is logischer om deze informatie in een folder op te nemen. Op het moment dat een klant vragen stelt, doet hij dat vooral vanuit nieuwsgierigheid en nauwelijks vanuit de overweging om duurzame vis te gaan eten blijkt tijdens de interviews (visseizoen en vangstgebied). Dit zou verder onder klanten onderzocht moeten worden.

- Het merendeel van de visdetaillisten merkt op dat hun klanten vooral geïnteresseerd zijn in kwaliteit en minder in duurzaamheid, zelfs als consumenten meer informatie over duurzame vis te horen krijgen die actief via Ngo's wordt verspreid. Desondanks noemt het merendeel van de visdetaillisten dat veel van hun klanten niet weten wat ze met alle gepubliceerde informatie over vis en duurzaamheid aan moeten en dat de kennis over vis bij klanten bijzonder klein is.

"Als ik merk dat een klant echt iets van vis of duurzame vis weet, begin ik hem/haar daar vragen over te stellen. Op die manier kom ik erachter of iemand de informatie van internet heeft gekopieerd zonder te weten waar het daadwerkelijk over gaat." 
"Ik merk dat mijn klanten uit nieuwsgierigheid vragen waar de betreffende vissoort is gevangen en niet omdat ze willen weten of het een duurzame vis is of niet. De meeste van hen stellen geen aanvullende vragen welke met duurzame vis verband hebben."

- De kennis van klanten over vis moet op een hoger peil gebracht worden door de klanten zelf.

Samenvattend lijkt het erop dat de meerderheid van de visdetaillisten de verantwoordelijkheid bij hun klanten legt. Als klanten niet vragen om de informatie zoals in de EU-regelgeving is vastgelegd (inclusief de duurzaamheidsinformatie zoals vangstgebied, visseizoen en vangstmethode), voelt de meerderheid van de visdetaillisten geen druk en noodzaak om deze informatie te delen. De ondervraagde visdetaillisten die de verplichte informatie wel (pro)actief communiceren doen dit vanuit persoonlijke motief. 


\title{
$5 \quad$ Reflecties
}

In dit hoofdstuk brengen we enkele punten onder de aandacht die tijdens het onderzoek zijn opgevallen of van belang kunnen zijn voor vervolgonderzoek.

\begin{abstract}
Verkenning
De verkenning geeft een goede eerste indruk van de communicatie over duurzame vis in de visdetailhandel. Bedacht moet echter worden dat de resultaten zijn verkregen via een enquête onder een groep van beperkte omvang. Binnen deze groep is aantal ondervraagden met een viswinkel (65\%) groter dan in de praktijk (50\% van de visdetaillisten heeft een viswinkel, zie hoofdstuk 1 ). Bovendien bestaat de indruk dat bezoekers van de Verspiratiebeurs de wat innovatievere ondernemers zijn (voorlopers). In die zin vormen de ondervraagden van de verkenning geen representatieve afspiegeling en is een uitgebreidere enquête nodig.
\end{abstract}

\section{Verschillen tussen locaties}

Zowel tijdens de verkenning als de diepte-interviews wijzen respondenten op een verband tussen verkooplocatie, samenstelling van de klantenkring en de samenstelling van het assortiment dat wordt verkocht. Op locaties met goedverdienende klanten, die meer te besteden hebben, worden luxere c.q. duurdere vissoorten verkocht terwijl op locaties met klanten in de lagere inkomensklassen minder dure vis en relatief veel gebakken vis wordt verkocht. Binnen een stad als Amsterdam constateren eigenaren van viswinkels deze verschillen bijvoorbeeld tussen Amsterdam-Zuid en Amsterdam-West. In welke mate dit klopt, elders plaatsvindt en of tussen dergelijke locaties ook verschillen bestaan in de vraag naar en verkoop van duurzame vis is een aandachtspunt voor onderzoek.

\section{Diversiteit: 'bonte groep'}

Uit zowel de verkenning als de diepte-interviews komt een enorme diversiteit aan bedrijfstypen van visdetaillisten naar voren. Ook de samenstelling van het assortiment dat wordt verkocht varieert (hoofdstuk 4). Een aandachtspunt voor de uitgebreidere enquête is of visdetaillisten die veel gebakken vis omzetten op dezelfde manier over duurzame vis communiceren als collega's die veel verse vis verkopen. Dat geldt overigens ook voor de klanten/consumenten van respectievelijk verse en gebakken vis: wat weten zij over duurzame vis en welke eisen hebben zij als ze vis kopen? In deze is een onderzoek onder consumenten naar kennis over duurzame vis nuttig, bijvoorbeeld om promotieactiviteiten over duurzame vis te kunnen initiëren.

\section{Stad versus platteland}

Tijdens de diepte-interviews bleek dat sommige visdetaillisten in de stad veel aandacht besteden aan de verkoop van duurzame vis en dat ze een klantenkring hebben die daar 'gevoelig' voor is. De vraag die hier opdoemt is of onder consumenten in een stad (zoals Amsterdam) meer aandacht bestaat voor duurzame vis dan in kleinere plaatsen op het platteland, elders in Nederland. De rol van de visdetaillist en de belangstelling van klanten voor duurzame vis spelen vermoedelijk een rol bij de communicatie over en de verkoop van duurzame vis (onderscheidt klanten in de stad en op het platteland).

\section{Verpakte en onverpakte vis}

Visdetaillisten verkopen naast onverpakte vis ook verpakte vis die verpakt is ingekocht. Ondervraagde visdetaillisten geven aan dat informatie over herkomstgebied, vangstmethode kweek of wild gevangen vaker bij verpakte vis op de verpakking staat dan wordt vermeld dan bij onverpakte vis. Een uitzondering hierop vormt de seizoeninformatie.

\section{Informatieoverdracht in de keten, meerdere leveranciers}

Visdetaillisten werken met meerdere leveranciers. Tijdens de diepte-interviews geven ondervraagde visdetaillisten aan dat hun leveranciers de gewenste duurzaamheidsinformatie per vissoort leveren of kunnen leveren. Het leveren van deze informatie blijkt echter niet altijd een automatisme. Ook bestaat er tussen leveranciers geen uniformiteit in de manier waarop deze informatie wordt aangeleverd (rekening, pakbon, sticker, mondeling bij opvragen); de ene leverancier zet het op de rekening, de ander op de pakbon en de derde geeft de informatie niet vanzelf door. Het gebrek aan automatisme 
en uniformiteit kost de visdetaillist extra tijd om de informatie per vissoort te vergaren en te vermelden. Onderzocht zou moeten worden in hoeverre de informatievoorziening tussen leverancier en visdetaillist imperfect is en welke verbeteringen nodig zijn en of ketenafspraken nodig zijn met het oog op uniformiteit en volledigheid van de informatie. Anderzijds zou ook nagegaan moeten worden in hoeverre visdetaillisten de duurzaamheidsinformatie die ze van hun leveranciers ontvangen ook daadwerkelijk in hun communicatie richting consument gebruiken.

\section{Visdetaillisten}

Voor de meeste visdetaillisten is kwaliteit (vers, vlezig) van de vis veel belangrijker dan of ze duurzame vis verkopen. Dat maakt dat ze niet proactief communiceren over duurzame vis: de consument/klant vraagt er niet om, wil kwaliteit. Slechts enkele van de ondervraagde visspecialisten communiceren over duurzame vis (o.a. storytelling), vanuit hun persoonlijke passie of omdat ze op de hoogte zijn van EU-regelgeving (EU, 2014).

\section{Duurzame visdetaillisten}

Van de visdetaillisten lijkt ruwweg tien procent goed bezig (voorloper) met duurzame vis, de overige negentig procent is onvoldoende of slecht geïnformeerd. Zij hebben het beeld dat (hun) klanten niet in duurzame vis geïnteresseerd zijn en besteden geen energie aan het inkopen en promoten van duurzame vis. Dat gaat volgens hen ten koste van de omzet.

\section{Vis van het seizoen - duurzame vis}

Klanten bezoeken de visdetaillist o.a. vanwege de 'vis van het seizoen'. Dit geeft de visdetaillist de mogelijkheid om het verhaal bij de vis aan klanten te vertellen inclusief een focus op duurzame vis (storytelling). Visdetaillisten zouden ook actiever over duurzame vis kunnen communiceren. Dit kan bijvoorbeeld ondersteund worden door een grote kaart met de zeeën en de herkomst van de verschillende vis en vistuigen in winkels op te hangen. Andere mogelijkheden zijn een website of een verwijzing naar een website, zorgen voor een scanbaar label, et cetera.

\section{Kennis over duurzame vis bij consumenten}

Visdetaillisten geven aan dat de kennis van hun klanten over vis en duurzame vis te wensen over laat. Het leeuwendeel van de klanten vindt kwaliteit en prijs belangrijker dan duurzaamheid. Slechts voor een klein deel van de klanten is de duurzaamheidsinformatie van de vis doorslaggevend voor een aankoop. Visdetaillisten geven aan dat de VISwijzer complex is. Onderzocht zou kunnen worden wat consumenten van de VISwijzer vinden en hoe ze deze gebruiken: te moeilijk/makkelijk, er staat onbekende vis op die niet gewenst is, et cetera.

Het feit dat klanten zelden naar duurzaamheid vragen wil niet zeggen dat ze er niet in geïnteresseerd zijn. Misschien verwachten ze wel dat het verkooppunt alleen maar duurzame vis heeft. In die zin is het zinvol om ook de behoefte en kennis van de klant over duurzaamheid in kaart te brengen.

\section{Kosten certificering}

Visdetaillisten noemen de kosten die nodig zijn voor het verkrijgen van een MSC- en ASC-certificering als een belangrijke belemmering. In geval van meerdere certificaten voor verschillende vissoorten leidt dat tot stapeling van kosten en (extra) werk. Dat vormt een belemmering voor de individuele visdetaillist om aan erkende certificeringsystemen deel te nemen. Sommige visdetaillisten zijn gedreven en starten hun eigen manier om zich met duurzame vis te onderscheiden: ze verkopen bijvoorbeeld 'groene vis'. Uit de interviews blijkt dat een beperkt deel van de visdetaillisten bij in- en verkoop aandacht heeft voor duurzame vis. De belangrijkste drijfveer is de persoonlijke overtuiging en de EU-regelgeving voor labeling. Niet onderzocht is of visdetaillisten met een certificaat ook meer over duurzaamheid communiceren.

\section{Internet-enquête}

Om eerder vermelde redenen (hoofdstuk 2 ) is geen uitgebreide nulmeting onder visspecialisten uitgevoerd. Op basis van fase 1 en 2 van het onderzoek kunnen hier enkele suggesties geformuleerd worden voor geval het toch nog mogelijk wordt de internet-enquête af te nemen:

- Vanwege de grote diversiteit aan ondernemingen van visdetaillisten dient gestreefd te worden dat voldoende respondenten uit elke subgroep de enquête invullen. Criteria in dit verband zijn 
bijvoorbeeld: type zaak (winkel, kraam, verkoopwagen), landelijke spreiding, (regio, platteland/stad) en samenstelling van de omzet (aandeel vers, gebakken, verpakt).

- Voor het afnemen van de enquête zijn voldoende contactgegevens van visdetaillisten nodig. Tijdens de bijeenkomsten van de begeleidingscommissie werd aangegeven dat er geen totaaloverzicht is van alle visdetaillisten in Nederland. Een optie is bij de Vereniging van Nederlandse Visspecialisten na te gaan of hun leden voor deelname aan de enquête benaderd kunnen worden. Aandachtspunt daarbij is de representativiteit: vormen de visspecialisten die lid zijn van de VNV een goede afspiegeling van de Nederlandse visdetaillisten.

- Visdetaillisten zijn hardwerkende ondernemers. Ze zijn niet snel geneigd een enquête in te vullen, zeker als het gaat over een onderwerp waar ze (nog) weinig mee hebben of het nut niet van inzien. Dit is nadelig voor de respons. Een mogelijkheid om de respons te verbeteren is om (een deel van) de enquêtes telefonisch af te (laten) nemen. Eventueel kan een beloning of een onder de deelnemers te verloten prijs in het vooruitzicht worden gesteld. Ook het terugkoppelen van de individuele scores en de groepstotalen (benchmark) kan aansporen tot deelname. Dit laatste geeft de deelnemer de mogelijkheid om de eigen positie te spiegelen aan die van collega-visdetaillisten. Bij een eventuele herhaling van de enquête kan de voortgang gemonitord worden.

- De voor de Nijkerk-verkenning opgestelde vragenlijst biedt een goed uitgangspunt voor de vragen van de internet-enquête. Het aantal vragen moet zeker niet groter worden. Focus op verse, onverpakte vis, en laat verpakte vis (verpakt ingekocht en ongeopend doorverkocht) buiten beschouwing.

- Op basis van de diepte-interviews bevelen we aan een enkele vraag toe te voegen over de informatieverstrekking over duurzame vis door leveranciers aan visdetaillisten om na te gaan of zich daar belemmeringen voordoen. Ook vragen over de visie van de visdetaillist over de kennis en informatiebehoefte over duurzame vis van klanten is nuttig. 


\section{Bevindingen}

De meest opvallende zaken van het onderzoek zijn:

1. De diversiteit aan bedrijfstype en ondernemers binnen de visdetaillisten is groot. Het bedrijfstype (viswinkel, kiosk, seafoodbar, ambulante handel (marktkraam, bakwagen) varieert evenals klantenkring, en de herkomst en aanbod van het visassortiment in de winkel). Winkels hebben een vaste locatie terwijl de meeste viskramen verschillende standplaatsen hebben. Ook komt voor dat een ondernemer zowel een winkel als een of meerdere marktkramen exploiteert.

2. Visdetaillisten kopen hun vis in bij meerdere leveranciers met wie zij een lange termijn inkooprelatie hebben. Vrijwel alle visdetaillisten noemen de kwaliteit als belangrijkste inkoopcriterium, en vinden de prijs van ondergeschikt belang. Een minderheid van visdetaillisten let bij de inkoop op de prijs/kwaliteit verhouding. Vertrouwen tussen visdetaillisten en hun leveranciers is de sleutel voor betrouwbare kwaliteit van de ingekochte vis. Voor de meeste visdetaillisten is duurzame vis een ondergeschikt of onbelangrijk aankoopcriterium.

3. Uit de interviews komt naar voren dat de knelpunten vooral zitten in de communicatie tussen de visdetaillist en zijn klanten. Het merendeel van de visdetaillisten communiceert niet actief over duurzame vis met hun klanten terwijl ze wel over de informatie (kunnen) beschikken. Ze denken dat klanten geen interesse hebben voor duurzame vis. Visdetaillisten die wel met hun klanten over duurzame vis communiceren geven aan dat het hun klanten interesseert en dat ze aan die klanten meer duurzame vis zijn gaan verkopen.

4. Visdetaillisten signaleren dat de samenstelling van de klantenkring per locatie varieert. In een buurt met mensen uit de hogere-inkomensgroepen hebben klanten heel andere wensen dan in een buurt met lage inkomens. Mensen met hoge inkomens prefereren luxere verse vis en klanten met lage inkomens hebben eerder voorkeur voor gebakken vis. Onderzocht zou kunnen worden of ook interesse voor en aankoop van duurzame vis tussen deze inkomensgroepen varieert.

5. Het label bij de vis in de vitrine is te klein voor extra informatie. Het label wordt in eerste instantie gebruikt om de prijs te communiceren: de prijs wordt naast de naam van de vis standaard op het label vermeld. Daarnaast wordt de prijs in de winkel of marktkraam ook op andere manieren gecommuniceerd: o.a. via posters, een monitor en/of mondeling.

6. Een groot deel van de ondervraagden geeft aan niet op de hoogte te zijn van de EU-regelgeving (EU, 2014).

7. De informatieoverdracht in de keten varieert. Alle visdetaillisten hebben toegang tot of ontvangen de benodigde verplichte informatie van hun leveranciers, inclusief de duurzaamheidsinformatie. De manier waarop deze informatie beschikbaar komt verschilt: sticker, rekening of afslagbrief. Sommige visdetaillisten ontvangen een rekening met beperkte informatie (soort, hoeveelheid en prijs). De visdetaillisten geven aan dat hun leveranciers eventuele specifieke vragen zoals vangstdatum kunnen beantwoorden.

8. Het zou handig zijn een meer uniforme manier af te spreken waarop verplichte informatie wordt verstrekt/uitgewisseld: dit vergroot de uniformiteit en bespaart de visdetaillisten inspanning en tijd. Het bij elkaar zoeken van deze informatie uit verschillende bronnen kost tijd.

9. De informatieverstrekking door visdetaillisten aan klanten gebeurt vooral mondeling en via labels. De mondelinge communicatie is het meest gangbaar in de visdetailhandel.

10. Klanten van visdetaillisten vinden kwaliteit (vers, vlezig) belangrijker dan de prijs van de vis. De meeste klanten hebben nog weinig affiniteit met duurzame vis. Dat zou kunnen betekenen dat deze klanten in supermarkten ook nauwelijks letten op het feit of ze duurzaam gecertificeerde vis kopen.

11. Naast een enquête onder visdetaillisten is ook een onderzoek onder consumenten en leveranciers nuttig om zicht te krijgen op de informatiebehoefte en -stromen in de keten. Deze onderzoeken kunnen handvaten bieden voor het bepalen van de meest optimale aanpak voor promotie en verkoop van duurzame vis. 


\section{Literatuur}

Boschma, Sien, 2016. Fish, buy, sell and love; insight in information, sustainability and communication in the Dutch fish monger sector. Rapport Afstudeeropdracht Van Hall Larensteijn/ Wageningen UR.

CBS (2015).

Detailhandel info. Website bezocht op 4 en 10 februari:

http://detailhandel.info/index.cfm/branches/foodspeciaalzaken/viswinkels/

Elsevier (2016). Milieuclubs profiteren flink van wantrouwens tegen visserij.

Europese Unie, 2014. Een pocketgids over de nieuwe EU-consumentenetikettering van visserij- en aquacultuurproducten.

Melissant, C., De Vos, B. \& Zaalmink, W. (2014). Keurmerken en labels voor verse Nederlandse vis; Een wegwijzer voor kenniskringen in de visserij. LEI, Wageningen UR.

Olthuis, L., (2015). Is de visboer op zijn blauwe ogen te vertrouwen? De Volkskrant 26 november 2015.

Olthuis, L., (2015). Viswinkels verkopen nauwelijks duurzame vis. De Volkskrant 26 november 2015.

Poel, Romy van der, (2016), Visverwarring: Welke vis is nog fris? NRC, 1 februari 2016. 


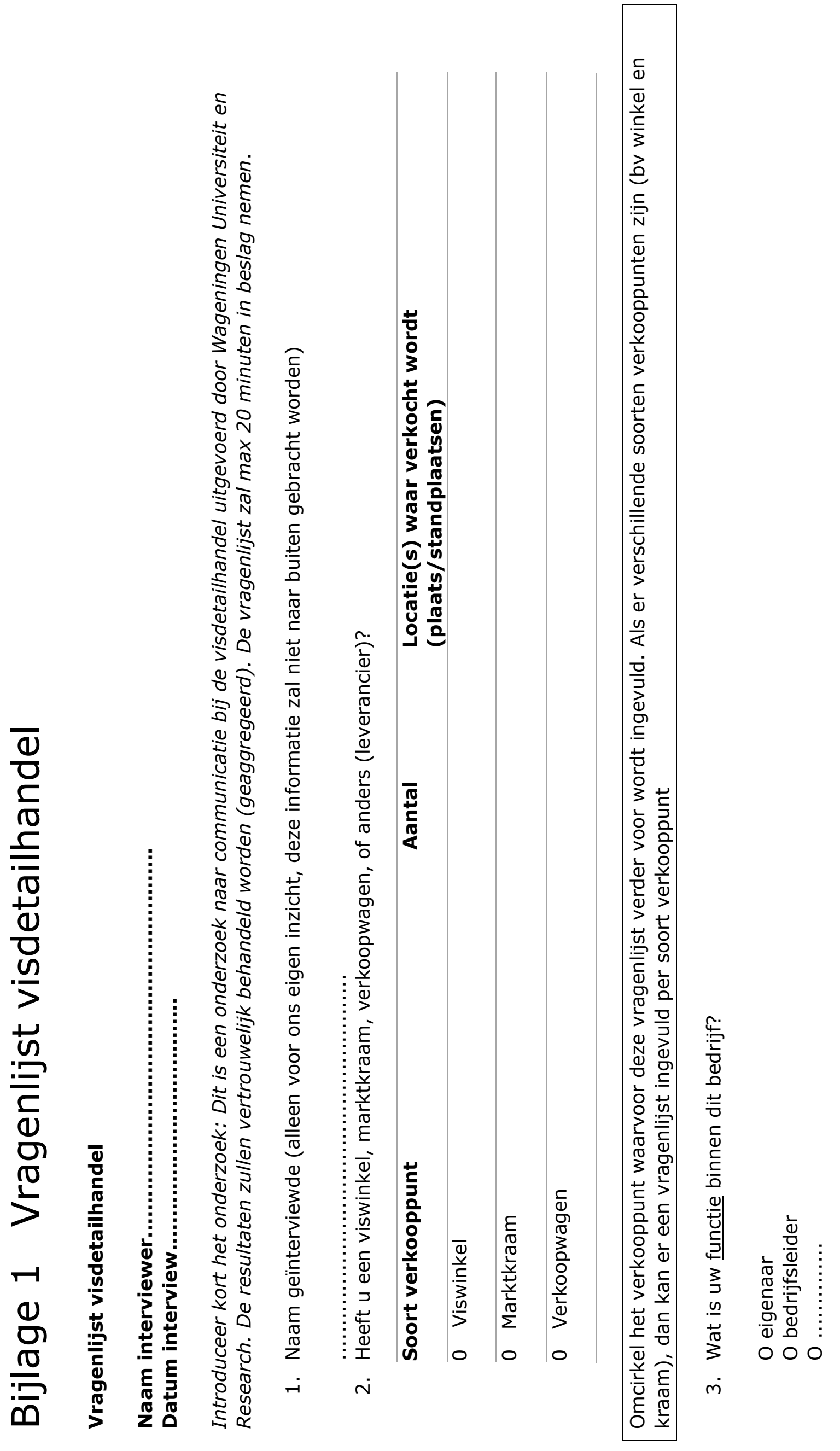




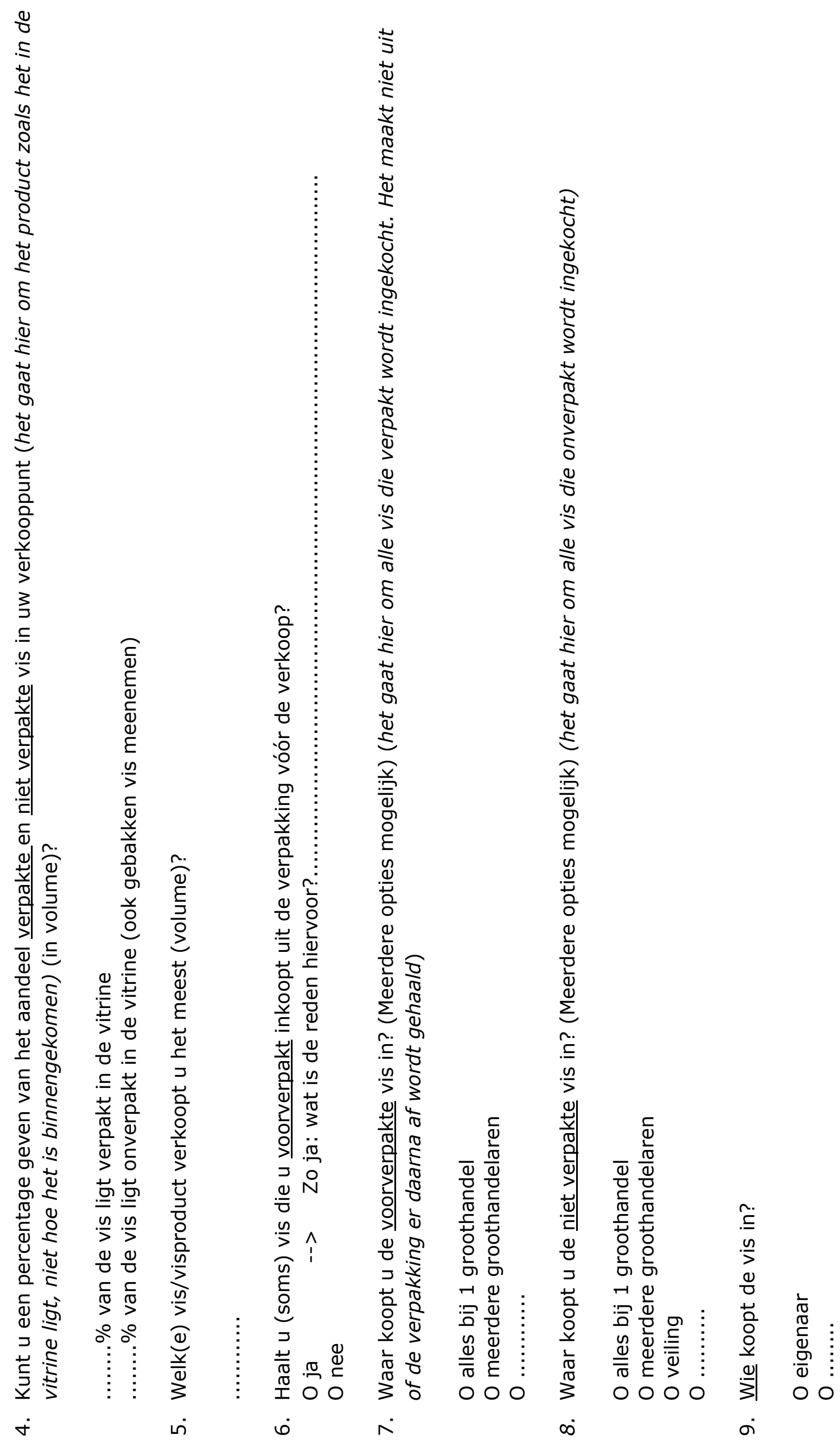

48 | Communicatie over duurzame vis in de visdetailhandel 


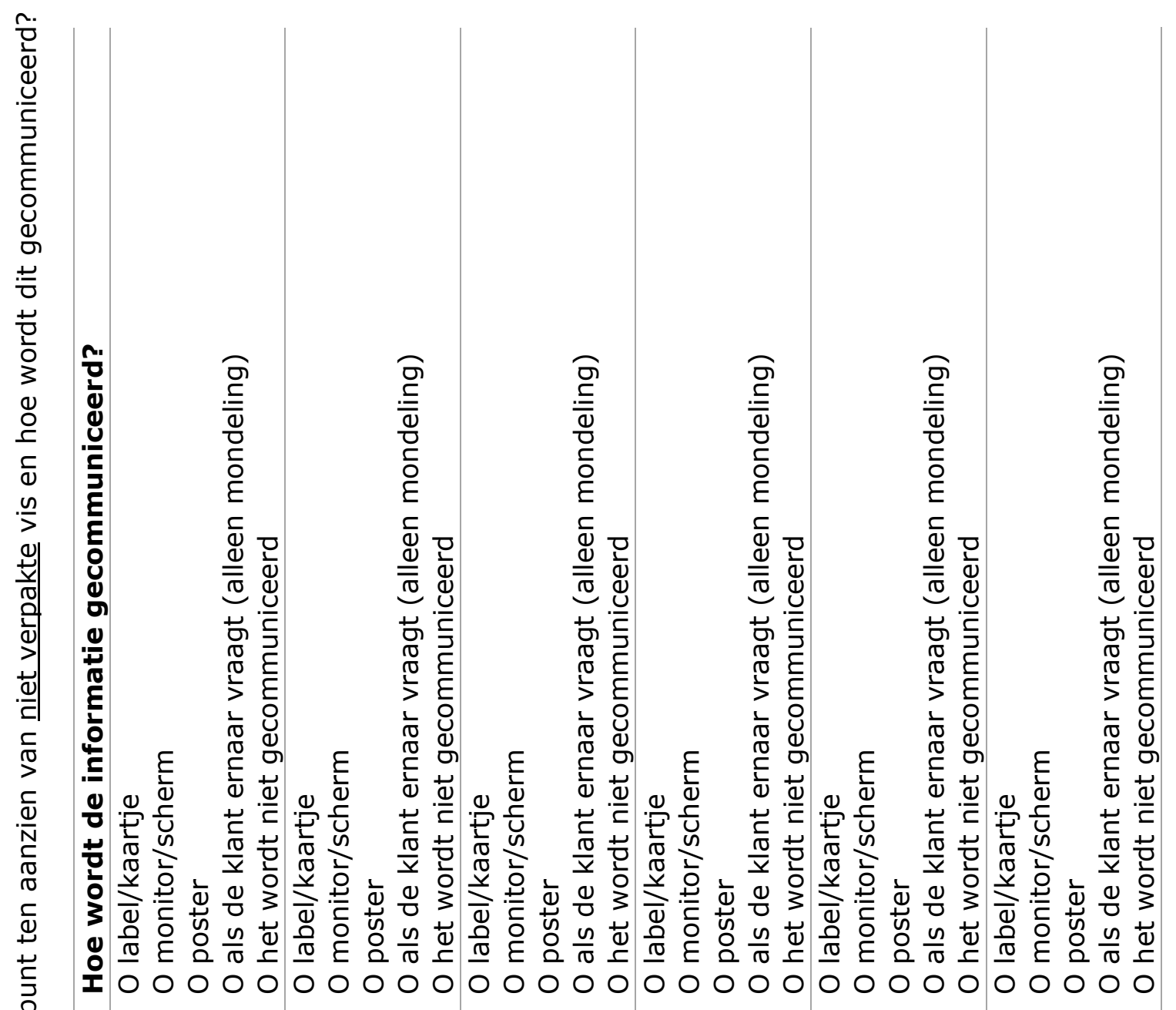




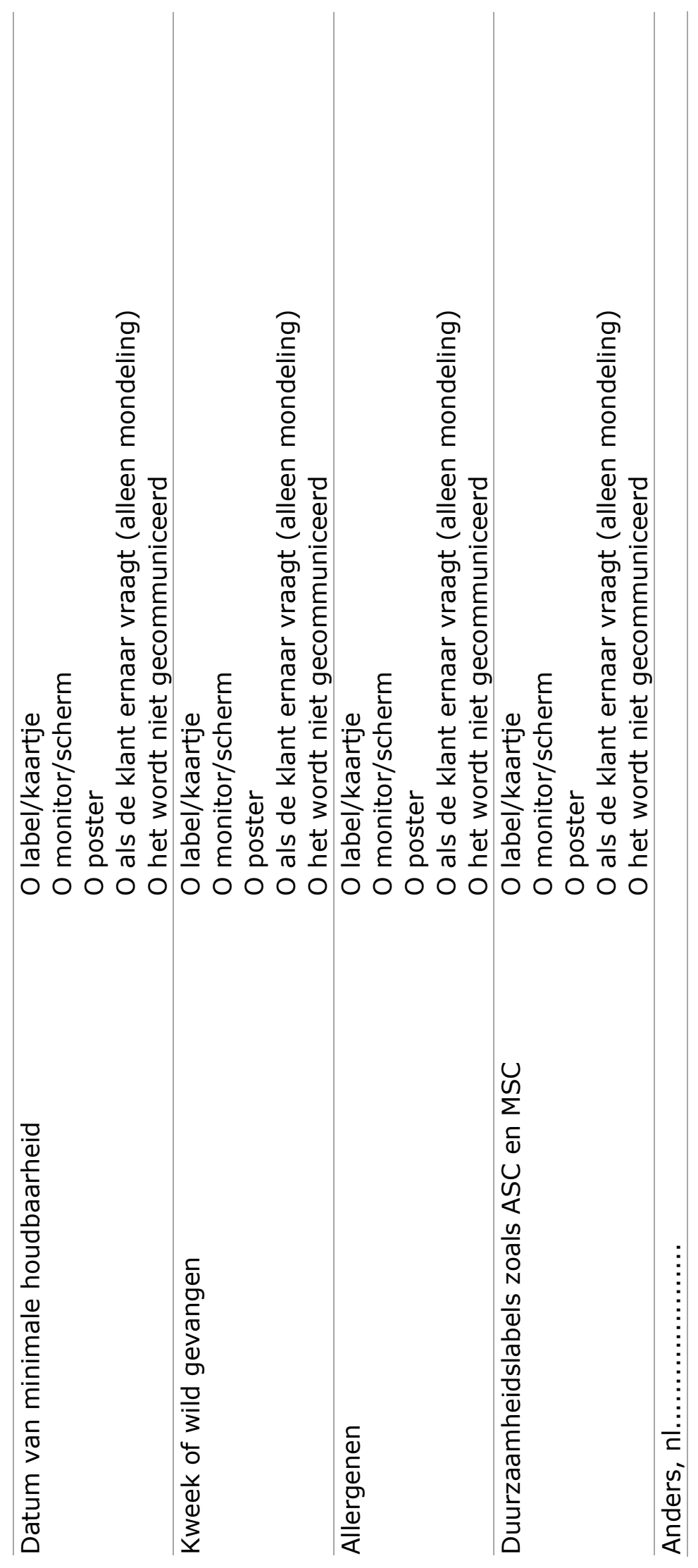

$50 \mid$ Communicatie over duurzame vis in de visdetailhandel 


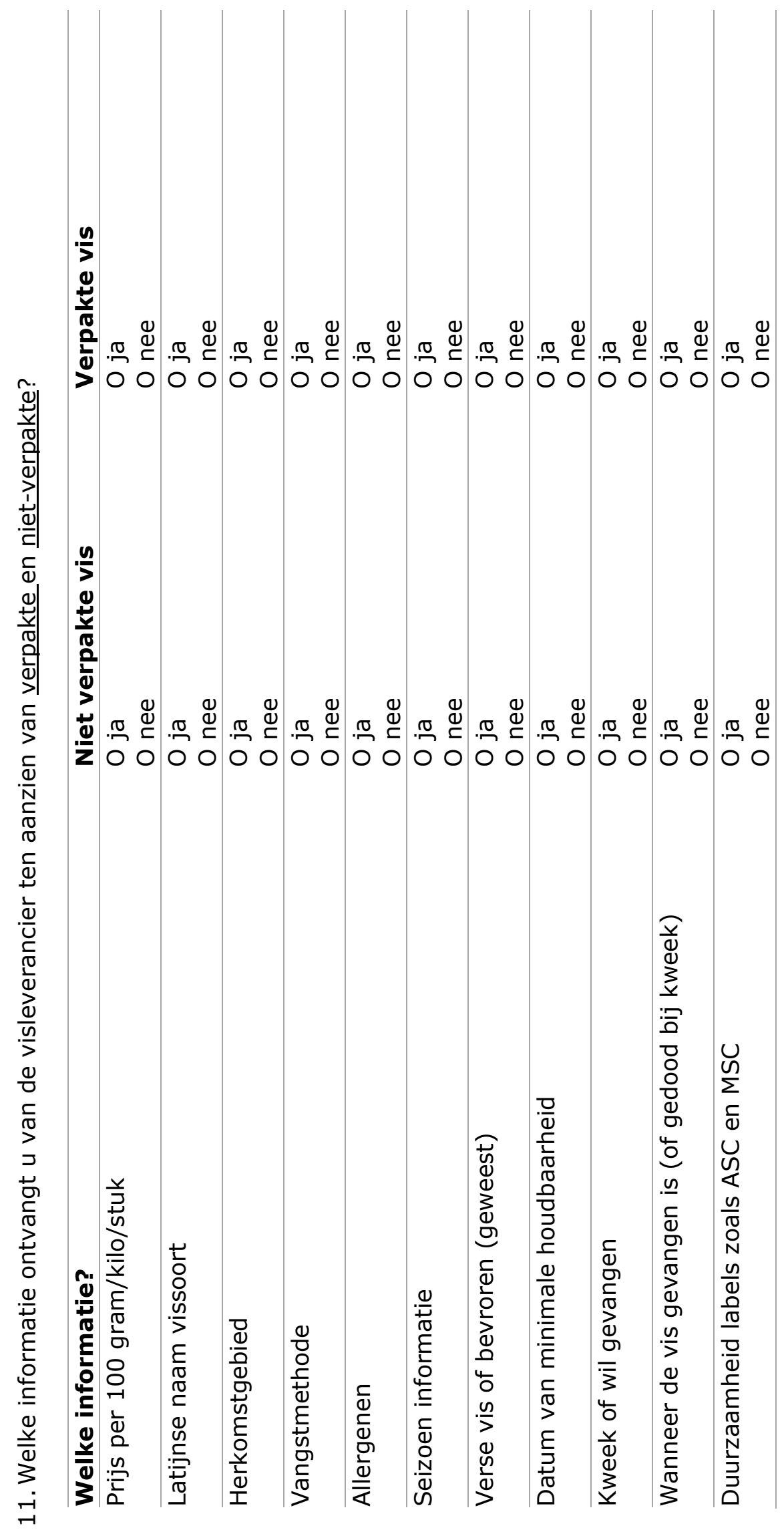




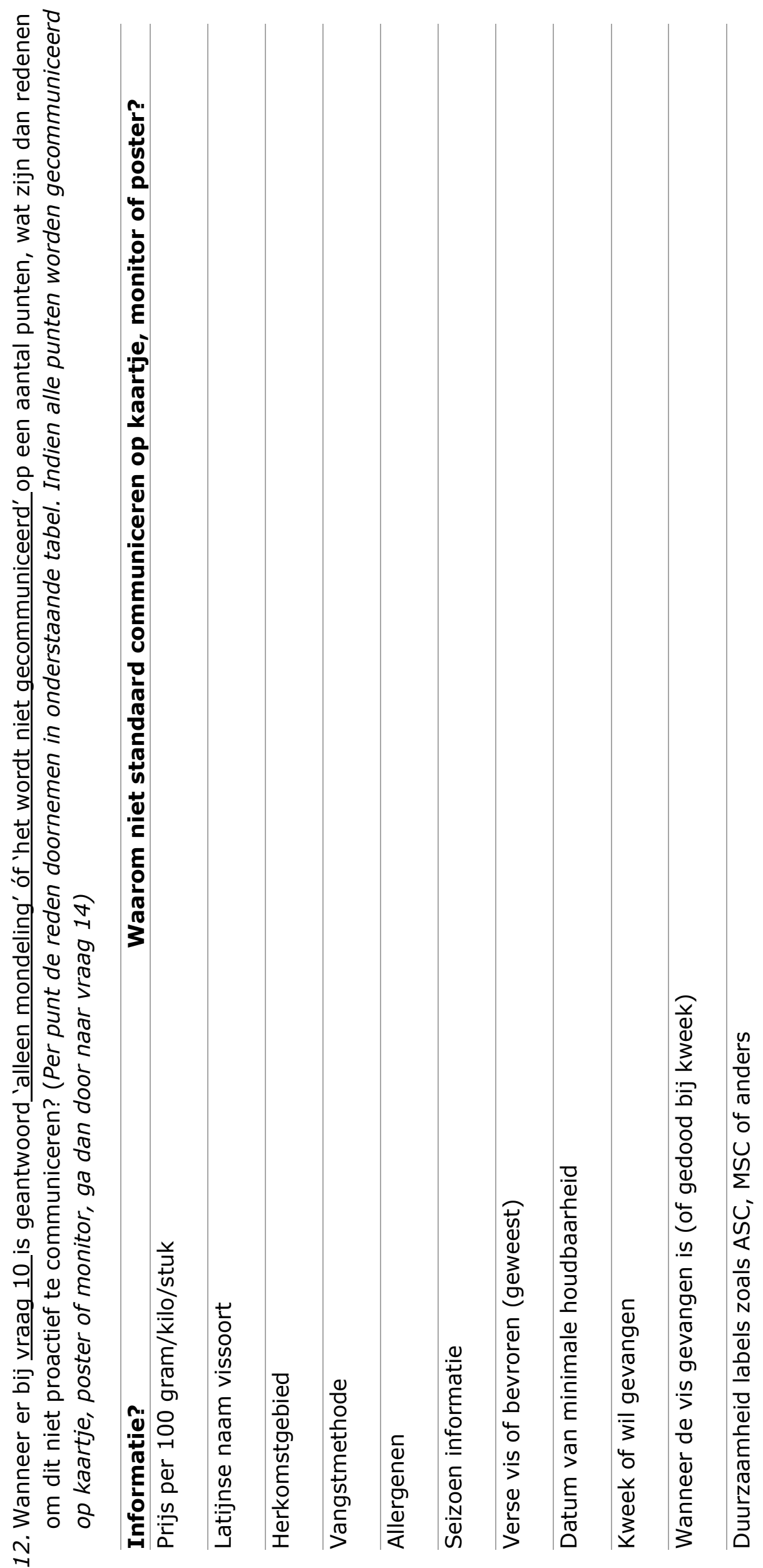




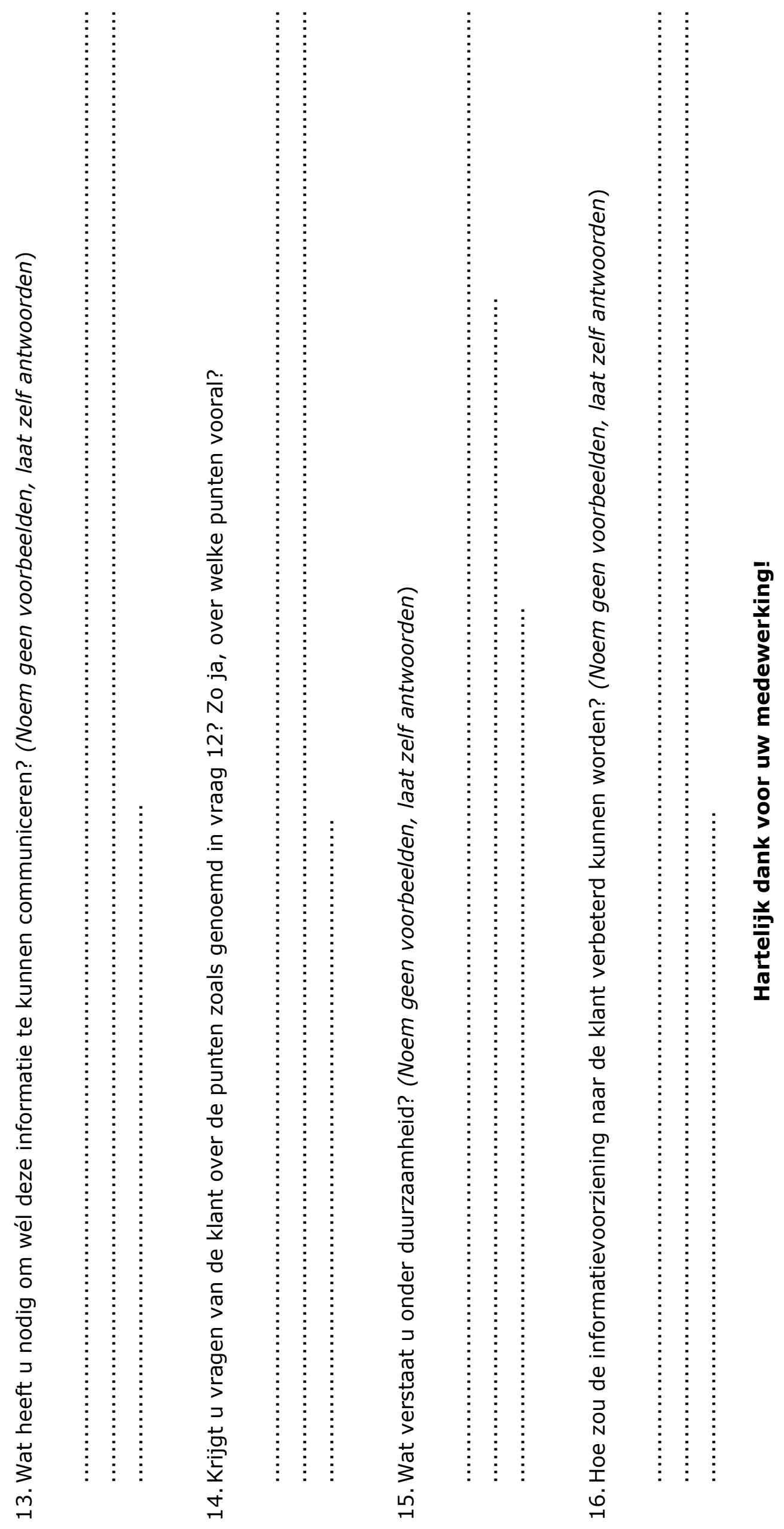

Rapport 339 | Wageningen, Wetenschapswinkel | 53 



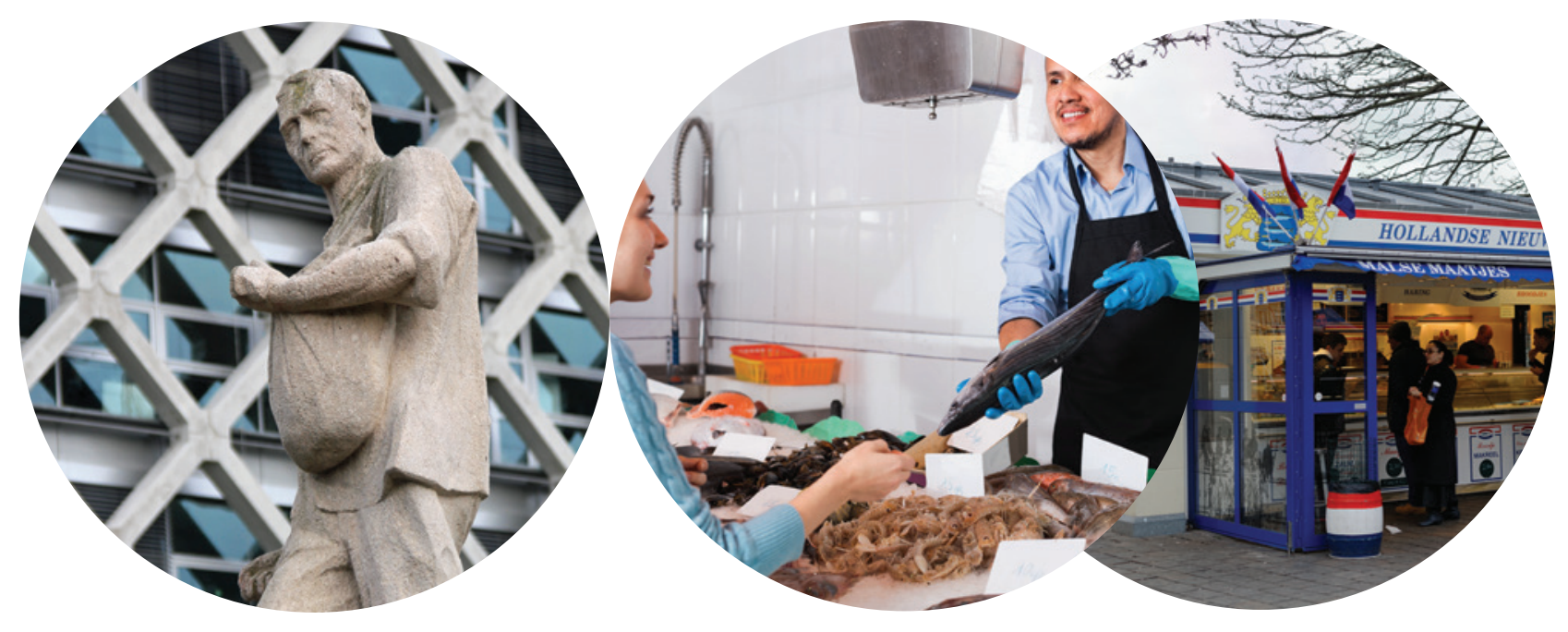

Wageningen University \& Research Wetenschapswinkel

Postbus 9101

6700 HB Wageningen

T (0317) 483908

E wetenschapswinkel@wur.nl

www.wur.nl/wetenschapswinkel
De missie van Wageningen University \& Research is 'To explore the potential of nature to improve the quality of life'. Binnen Wageningen University \& Research bundelen Wageningen University en gespecialiseerde onderzoeksinstituten van Stichting Wageningen Research hun krachten om bij te dragen aan de oplossing van belangrijke vragen in het domein van gezonde voeding en leefomgeving. Met ongeveer 30 vestigingen, 5.000 medewerkers en 10.000 studenten behoort Wageningen University \& Research wereldwijd tot de aansprekende kennisinstellingen binnen haar domein. De integrale benadering van de vraagstukken en de samenwerking tussen verschillende disciplines vormen het hart van de unieke Wageningen aanpak. 